\title{
Patrimônio e desenvolvimento: as políticas de patrimônio cultural nos anos 1960
}

\section{Claudia Feierabend Baeta Leal ${ }^{1}$}

RESUMO: O objetivo deste artigo é analisar especificidades dos anos 1960 no que diz respeito às políticas de patrimônio, destacando algumas mudanças de entendimentos, noções e propostas, notadamente referentes às relações entre desenvolvimento, cultura e patrimônio trabalhadas pelo Instituto do Patrimônio Histórico e Artístico Nacional, então Diretoria do Patrimônio Histórico e Artístico Nacional (DPHAN). Para tanto, vai-se partir das discussões e debates desse momento acerca dos efeitos da industrialização, do crescimento urbano e das políticas desenvolvimentistas sobre as políticas de patrimônio a partir dessa década, analisando as iniciativas voltadas à patrimonialização de bens culturais, à preservação do acervo que compunha o patrimônio histórico e artístico nacional e ao fomento de suas potencialidades econômicas. Na discussão proposta neste artigo, priorizar-se-ão os entendimentos e ações de preservação da DPHAN relacionados a identificação, valoração e proteção dos bens culturais, assim como os diálogos disciplinares e institucionais que a diretoria procurou estabelecer.

PALAVRAS-CHAVE: Patrimônio, Desenvolvimento, Diretoria do Patrimônio Histórico e Artístico Nacional - DPHAN.

ABSTRACT: This article aims at analyzing aspects of 1960s Brazilian cultural heritage policies, highlighting changes related to the articulation of concepts such as development, culture and heritage within the Directory of National Historical and Artistic Heritage - DPHAN, today Institute of National Historical and Artistic Heritage (IPHAN). It discusses the effects of industrialization, urban growth and development improvement measures on heritage concepts and policies, analyzing initiatives that focus on preserving cultural assets acknowledged as national historical and artistic heritage and enhancing their economical potential. The discussion emphasizes notions and understandings on heritage and preservation that had substantial bearing on preservation measures carried on by DPHAN from the 1960s on regarding the identification, valorization and protection of cultural heritage, as well as the disciplinary and institutional debates this Directory proposed.

KEYWORDS: Heritage, Development, Directory of National Historical Artistic Heritage DPHAN.

\begin{abstract}
1. Técnica em História da Coordenação de Pesquisa e Documentação do Departamento de Articulação e Fomento, do Instituto do Patrimônio Histórico e Artístico Nacional (Copedoc/DAF/ IPHAN); professora doutora do mestrado profissional em Preservação do Patrimônio Cultural do Iphan. Email<claudialeal@ iphan.gov.br>
\end{abstract}


2. O Iphan teve diferentes nomenclaturas ao longo de seus quases 80 anos de existência: inicialmente Serviço do Patrimônio Histórico e Artístico Nacional (SPHAN), tornou-se Diretoria (DPHAN) em 1946 e Secretaria em 1979 (SPHAN). Ainda em 1979, criou-se o sistema SPHAN/PróMemória, com a incorporação da Fundação Nacional Pró-Memória à estrutura da secretaria. Em 1981, manteve a sigla, mas tornou-se subsecretaria, voltando a ser Secretaria com a criação do Ministério da Cultura, em 1985. Em 1990, foi substituído pelo Instituto Brasileiro de Patrimônio Cultural (IBPC), passando à categoria de instituto e à sigla Iphan que permanece hoje em 1994. Cf. Iphan, 2009.

3. Ver Lia Calabre (2009, p. 63); Marcia Sant'Anna (2015, p. 203).

4. Conforme, entre outros, Maria Cecília Londres Fonseca (2005); Brasil (1980).

5. Ver Brasil (1980).

6. Cf. Julia Wagner Pereira (2009, p. 73).

7. Cf. Marcia Sant'Anna (2015, p. 209). Vale destacar também outros exemplos de estudos que deram destaque à gestão de Renato Soeiro, produzindo análises valiosas sobre o período, como esse livro de Sant'Anna, originalmente sua dissertação de mestrado; o trabalho de Julia Wagner Pereira (2009), citada acima; e também a dissertação defendida por Sandra Corrêa na Universidade de Brasília (2012).
Nos estudos do campo do patrimônio, no Brasil, a década de 1960 é usualmente tratada em termos de continuidade de políticas institucionais, o que em grande parte se deve a abordagens que procuram salientar, mais do que características dos diversos momentos históricos, a unidade da gestão de Rodrigo Melo Franco de Andrade à frente do Serviço do Patrimônio Histórico e Artístico Nacional e, em seguida, da Diretoria do Patrimônio². Nem mesmo o golpe militar de 1964 e a escassez de verbas para o campo da cultura naquele momento recebem muito destaque nessa trajetória, uma vez que a continuidade de gestão teria evitado rupturas na administração do órgão ${ }^{3}$. Especificidades e rupturas tendem a ser inseridas um pouco mais adiante, já na década de 1970, com programas como o Programa de Cidades Históricas (PCH), com a gestão de Aloísio Magalhães, a incorporação do Centro Nacional de Referências Culturais pela então Secretaria do Patrimônio Histórico e Artístico Nacional e a criação da Fundação Nacional PróMemória.

A periodização mais corrente da constituição do campo do patrimônio no Brasil trabalha com duas fases - "fase heroica" e "fase moderna" -, que corresponderiam, respectivamente, às gestões de Franco de Andrade e Magalhães 4 . A gestão de Renato Soeiro, que corresponde ao período que vai da aposentadoria de Franco de Andrade, em 1967, à entrada de Magalhães, em 1979, é chamada simplesmente de "segunda fase" por uma historiografia oficial da instituição ${ }^{5}$, com ênfase, portanto, no fato de ter-se então um segundo diretor para o órgão. Algumas análises sobre tal período tendem até a entendê-la "como uma extensão dos primeiros trinta anos do IPHAN, sem grande autonomia e mudanças" ${ }^{\circ}$, homogeneizando, portanto, um período demasiado longo e diverso, apagando mudanças e especificidades do contexło e desconsiderando, em larga medida, a importância do período para "a modernização do aparelho estatal de preservação do patrimônio"7.

O objetivo deste artigo é exatamente trabalhar com algumas especificidades dos anos 1960 no que diz respeito às políticas de patrimônio, destacando algumas mudanças de entendimentos, noções e propostas daquele momento, notadamente referentes às relações entre desenvolvimento, cultura e patrimônio, bastante evidenciadas no decênio seguinte, mas já expressas, promovidas ou apropriadas pela Diretoria do Patrimônio Histórico e Artístico Nacional, principal responsável então por tais políticas. Para tanto, vai-se partir das discussões e debates acerca dos efeitos da industrialização, do crescimento urbano e das políticas desenvolvimentistas - as quais marcavam o cenário nacional já desde a década de 1950, motivando preocupações e reações mais sistemáticas nos anos 1960 - sobre as políticas de patrimônio, analisando as iniciativas voltadas à patrimonialização de bens culturais, à preservação do acervo que compunha o patrimônio histórico e artístico nacional e ao fomento de suas potencialidades econômicas. Nesse sentido, para pensar as políticas de patrimônio cultural do período, priorizar-se-ão os entendimentos e as ações de preservação promovidas pela DPHAN relacionados à identificação, valoração e proteção patrimônio, assim como os diálogos disciplinares e institucionais que a diretoria procurou estabelecer nos anos 1960. 
No que diz respeito aos entendimentos de patrimônio e preservação e às ações de proteção priorizadas no contexto analisado, propõe-se aqui descrevêlos como tentativas de resistência aos avanços da urbanização sobre o patrimônio e, simultaneamente, de apropriação de aspectos do desenvolvimento nas suas ações voltadas à preservação. Destaca-se, por um lado, a preocupação com a exploração econômica desordenada e as iniciativas para racionalizar, impedir ou mitigar os impactos, por meio de medidas que reforçassem a efetividade ou garantissem a possibilidade de preservação dos bens; por outro, a busca por estratégias de compatibilização entre desenvolvimento e preservação. No que diz respeito às primeiras, este artigo aponta $\mathrm{O}$ investimento em instrumentos e procedimentos já disponíveis, como o tombamento, buscando, porém, alcançar objetos em perigo e que ainda não compunham, nos anos 1960, o rol mais consagrado dos bens protegidos - como os bens naturais e os conjuntos urbanos; destaca também o recurso a instrumentos complementares para a preservação de bens específicos, como a publicação da Lei da Arqueologia (Lei n 3924/1961), em que ficou evidente a participação de outros atores e instituições na preocupação com a preservação do patrimônio histórico e artístico nacional. Já no que diz respeito a estratégias para compatibilizar desenvolvimento e preservação, buscouse, neste artigo, relacionar as discussões sobre o tema no âmbito da DPHAN e do Estado brasileiro aos debates internacionais, em especial no que diz respeito à relação proposta entre turismo e preservação do patrimônio, destacando, nesse sentido, os diálogos entre DPHAN e Unesco.

artigo procura, em um primeiro momento, identificar e analisar os debates nacionais e internacionais acerca das relações possíveis entre desenvolvimento e patrimônio nos anos 1960, voltando a atenção para as preocupações com os efeitos dessas relações, mas, principalmente, para as tentativas de articulação tão harmônica quanto possível entre crescimento e preservação, tendo o turismo como uma importante alternativa. Na segunda parte, com vistas a problematizar alguns contextos em que as tentativas de compatibilização entre desenvolvimento e preservação não se mostraram suficientes para impedir danos e destruição, dar-se-á ênfase às discussões sobre medidas tomadas no Brasil com vistas a assegurar a preservação de certos bens culturais mais sujeitos a danos pelos avanços desenvolvimentistas - como os sítios e monumentos arqueológicos, os bens naturais e os conjuntos urbanos - e aos efeitos desses debates no que tange entendimentos sobre o patrimônio e sobre ações concretas tomadas a partir da década de 1960.

Compatibilizando patrimônio e desenvolvimento

Ao longo dos anos 1950 e 1960, é possível notar um movimento crescente no sentido de se aliar desenvolvimento econômico e interesse público, em especial no contexto dos países ditos "em desenvolvimento", como o Brasil. 0 governo de Juscelino Kubistchek (1955-1961) é tratado como um marco da aceleração desenvolvimentista, industrial, urbana e também rodoviária do que se 
8. Ver, nesse sentido, a "Exposição de motivos submetida pelo Ministro Gustavo Capanema ao Presidente Getúlio Vargas em novembro de 1937", transcrita em Brasil (1980, p.109-110)

9. Cf. Isabelle Cury (2004, p. 81).

10. Ver Isabelle Cury (2004, p. 81).

11. Ver Unesco, 1954. convencionou chamar, na historiografia nacional, de Segunda República. Tratavase de um sentido atribuído ao interesse público que se distinguia bastante daquele vigente nos anos 1930, notadamente no Brasil, em que estavam evidentes, principalmente, referências à construção de uma identidade nacional ${ }^{8}$.

No entanto, esse interesse público marcado pelo desenvolvimento não necessariamente ia ao encontro das necessidades e perspectivas da preservação do patrimônio histórico e artístico nacional. Antes, pelo contrário, parecia significar ameaças aos bens protegidos e àqueles potencialmente patrimonializáveis, sobre os quais ainda não incidiam ações sistemáticas de preservação.

No âmbito internacional, tais preocupações foram sistematizadas em importantes documentos de encontros promovidos nos anos 1960: são exemplos disso a Recomendação de Paris relativa à salvaguarda da beleza e do caráter das paisagens e sítios, de 1962, promovida pela Unesco; as Normas de Quito, elaborada no âmbito da Organização dos Estados Americanos, na Reunião sobre conservação e utilização de monumentos e sítios de interesse histórico e artístico, em 1967; e a Recomendação de Paris sobre a conservação dos bens culturais ameaçados pela execução de obras públicas ou privadas, resultado da $15^{a}$ Conferência Geral da Unesco, de novembro de 1968.

O primeiro documento, elaborado durante a $12^{a}$ sessão da Conferência Geral da Unesco, em 1962, que teve como foco específico a salvaguarda da beleza e do caráter das paisagens e sítios, fazia referência a uma série de perigos causados pela aceleração de ações acusadas de "desenvolver por vezes desordenadamente os centros urbanos, executar grandes obras e realizar vastos planejamentos físicos territoriais e instalações de equipamento industrial e comercial"9. Entre esses, estavam a "construção de edifícios públicos e privados de qualquer natureza"; a "construção de estradas"; as "linhas de eletricidade"; a "construção de auto-serviços para distribuição de combustíveis"; a distribuição indiscriminada de "cartazes publicitários e anúncios luminosos"; questões concernentes ao meio ambiente como o desmatamento, a polvição do ar e da água, a "exploração de minas e pedreiras e evacuação de seus resíduos", bem como a "captação de nascentes, trabalhos de irrigação, barragens, canais, aquedutos, regularização dos cursos de água etc."; além do descarte do lixo, por causa dos "depósitos de material e de matérias usadas, assim como detritos e dejetos domésticos, comerciais ou industriais".

É certo que a preocupação com "atentados que empobrecem o patrimônio cultural, estético e até mesmo vital", cometidos pela humanidade "em todas as épocas" 10 não era então inédita. Em 1954, fora elaborada a Convenção para Proteção de Bens Culturais em Caso de Conflito Armado "1, que destacou os "graves danos" sofridos por bens culturais durante as Primeira e Segunda Guerras Mundiais e as ameaças a que continuavam submetidos devido ao desenvolvimento de tecnologia de guerra. No entanto, a ênfase do documento está nos danos decorrentes de momentos excepcionais, como o são os conflitos armados referidos 
no título, e não da ação sistemática e cotidiana do homem sobre o espaço e a natureza, conforme se nota na Recomendação de 1962.

$\bigcirc$ desenvolvimento econômico e sua relação com a preservação do patrimônio é um tema que aparece de forma ainda mais premente nas Normas de Quito, de 1967; premência essa justificada pelo contexto de "grande empenho progressista" vivido então pelos Estados americanos que participavam do encontro, com destaque para a "exploração exaustiva de seus recursos naturais", a "multiplicação de obras de infraestrutura e a ocupação de extensas áreas por instalações industriais e construções imobiliárias"12. Contra o "processo anárquico de modernização" que teria sido entronizado nesses países, as Normas propuseram uma "solução conciliatória" que se voltasse para a preservação de seus monumentos culturais e de suas riquezas naturais e que se baseava na valorização econômica destes:

Em suma, trata-se de mobilizar os esforços nacionais no sentido de procurar o melhor aproveitamento dos recursos monumentais de que se disponha, como meio indireto de favorecer o desenvolvimento econômico do país. Isso implica uma tarefa prévia de planejamento em nível nacional, ou seja, avaliação dos recursos disponíveis e a formulação de projetos específicos dentro de um plano de ordenação gerall ${ }^{13}$.

Isso significava uma compreensão de que os bens culturais eram, como se lê no documento, "suscetíveis de constituir-se em instrumentos do progresso"; de que Estados deveriam investir na "revalorização do patrimônio monumental em função do interesse público e para benefício econômico da nação"; e de que essas medidas contribuiriam para solucionar os problemas referentes à própria preservação dos bens, em especial por meio de sua vinculação aos interesses turísticos ${ }^{14}$.

A Recomendação de Paris sobre a conservação dos bens culturais ameaçados pela execução de obras públicas ou privadas, resultado da $15^{\text {a }}$ Conferência Geral da Unesco, de novembro de 1968, não só mantém, como destaca já no título, a preocupação com os efeitos das ações humanas sobre o patrimônio, enfatizando as ameaças que estariam representadas pelas "obras públicas ou privadas" detalhadas nos seus "Princípios gerais"15. Da mesma forma como no documento de 1967, não há um questionamento sobre a legitimidade ou importância dessas obras; antes, sublinha-se o caráter inexorável, quase natural das mudanças causadas por tais empreendimentos, descritos como efeito da "industrialização e urbanização a que tende a civilização mundial no desenvolvimento dos povos e em sua completa realização espiritual e nacional" ou como "transformações exigidas pelo desenvolvimento social e econômico", mesmo representando ameaças aos "monumentos, testemunhos e vestígios do passado pré-histórico, proto-histórico e histórico, assim como [a] inúmeras construções recentes que têm uma importância artística, histórica ou científica"16.

Vale mencionar aqui o evento que a Unesco descreve como motivador das discussões que teriam levado à elaboração da noção de patrimônio mundial,
12. Cf. Isabelle Cury (2004, p. 107-108)

13. Ibid. (p. 110).

14. Cf. Isabelle Cury (2004, p. 105,107 e 112).

15. Ibid. (p. 127).

16. Ibid. (p. 124, grifos nossos). 
17. Sobre o salvamento dos templos de Abu Simbel, ver Unesco (2008, p. 7); Claudia Feierabend Baeta Leal (2008, p. 24). Vale mencionar que a alternativa utilizada no caso dos templos de Aswan, no Egito - que teriam sido desmontados, movidos para um lugar a salvo da inundação provocada pela represa e novamente montados - está descrita no ponto 11 da Recomendação de 1968: "As edificações e outros monumentos culturais importantes que tenham sido trasladados para evitar sua destruição por obras públicas ou privadas deveriam ser reinstalados em um sítio ou ambiente semelhantes ao de sua implantação primitiva e ao de suas vinculações naturais, históricas ou artísticas", cf. Isabelle Cury (2004, p. 128)

18. Cf. Isabelle Cury (2004, p. 124 , grifos no original).

19. Em seus princípios gerais, a Recomendação de Paris, de 1968, indica que as medidas de preservação de bens culturais devem se estender à totalidade do território; que os bens importantes devem ser conhecidos por meio de i n v e n t á $r$ i o s , independentemente de haver proteção legal aos mesmos; que as medidas destinadas ao seu salvamento devem ter caráter preventivo $\mathrm{e}$ corretivo; além disso, que deve ser dada a prioridade de manutenção dos mesmos in situ. Ver Isabelle Cury (2004, p. 126-128).

20. Ibid (p. 126 e 124).

21. Cf. Brasil (1980, p. 20).

22. Cf. Maria Cecília Londres Fonseca (2005, p. 142). intimamente relacionado aos impactos de obras sobre o patrimônio cultural: trata-se da construção da represa de Aswan, no Egito, em 1959, que teria mobilizado a própria Unesco e a comunidade internacional numa campanha de arrecadação de fundos para o salvamento dos templos de Abu Simbel17.

É importante também indicar, ainda nessa Recomendação de 1968, a relação que se percebia ou que se propunha entre preservação do patrimônio cultural e desenvolvimento social e econômico. Ambos são postos como deveres dos governos e como elementos necessários para o bem-estar e a realização dos povos; são, porém, simultaneamente, também descritos como aspectos em conflito, dadas as ameaças representadas pelo desenvolvimento à "herança cultural da humanidade". Daí a proposta de harmonização de ambos:

Considerando, portanto, que é necessário harmonizar a preservação do patrimônio cultural com as transformações exigidas pelo desenvolvimento social e econômico, e que urge desenvolver os maiores esforços para responder a essas duas exigências em um espírito de ampla compreensão e com referência a um planejamento apropriado;

Considerando, igualmente, que a adequada preservação e exposição dos bens culturais contribuem poderosamente para o desenvolvimento social e econômico dos países e das regiões que possuem esse gênero de tesouros da humanidade, através do estímulo ao turismo nacional e internacional; $(\ldots)^{18}$.

A forma ensejada para "harmonizar" preservação e desenvolvimento dar-se-ia, como se lê acima, por meio de um "planejamento apropriado" e de medidas que, entre outros aspectos ${ }^{19}$, previssem a manutenção de "inventários atualizados de bens culturais importantes, protegidos por lei ou não", principalmente se "situados em locais em que obras públicas ou privadas os ameacem"; valorizassem a vinculação da população local aos bens culturais, como forma de garantir sua preservação; e que estimulassem a apropriação desses bens pelo turismo20, tema que, como se verá diante, marcou as discussões sobre desenvolvimento e patrimônio dos anos 1960 no âmbito da Unesco.

Na historiografia referente à DPHAN, a relação entre desenvolvimento, industrialização, urbanização, de um lado, e preservação do patrimônio, de outro, foi descrita como um tema particularmente relevante nos anos 1960, quando teria representado uma revisão de diretrizes: "O rápido desenvolvimento urbanístico e viário do país, sua crescente industrialização e sobretudo a valorização imobiliária daí decorrente impuseram a implantação de medidas mais enérgicas e abrangentes" 21. Maria Cecília Londres Fonseca fala da necessidade de "reformular e reforçar sua atuação, visando a compatibilizar os interesses da preservação ao modelo de desenvolvimento então vigente no país" 22. Para essa autora, nacionalismo e modernização teriam sido atrelados sob a ideia do desenvolvimentismo, e os argumentos que giravam em torno do valor cultural dos bens não mais bastavam: era preciso "demonstrar a relação entre valor cultural e valor econômico". Fonseca deu destaque às tensões que surgiram no âmbito da instituição no que concernia 
à "preservação das cidades históricas e dos centros históricos das grandes cidades", à "proteção dos conjuntos e do entorno de monumentos" dada a valorização e especulação imobiliária. Márcia Sant'Anna também sublinhou a demanda da DPHAN por "novas soluções" e por uma "política para a conservação do patrimônio" frente aos problemas urbanos advindos da arrancada industrial que impedia que a atuação da instituição se voltasse principalmente, como até então ocorria, para "problemas de manutenção das (...) características formais" dos conjuntos e monumentos ${ }^{23}$.

As orientações para a revisão de diretrizes, ainda segundo essa historiografia, teriam vindo por meio do estreitamento das relações entre DPHAN e Unesco ${ }^{24}$. Os contatos entre as duas instituições tornaram-se mais fortes nessa década de 1960, época em que a Unesco "dava passos em direção à descentralização" e estabeleceu sua representação no Brasil, "como parte do acordo de cooperação técnica firmado com as autoridades brasileiras em 1964" 25 . Na constituição desse acordo de cooperação técnica, duas figuras de relevo teriam sido o crítico de arte e cientista político brasileiro Lourival Gomes Machado, que ocupava o posto de diretor de assuntos culturais da Unesco, e Rodrigo Melo Franco de Andrade, então diretor da DPHAN, o que teria propiciado uma série de missões de peritos internacionais ao Brasil26.

Essas missões devem ser entendidas dentro da perpectiva de cooperação internacional, formulada de maneira bastante clara desde 1945 no documento que lançou as bases da Unesco. No texto de sua Constituição, nota-se a ênfase na "cooperação entre as nações em todos os ramos de atividade intelectual", por meio do "intercâmbio internacional de pessoas ativas nos campos da educação, da ciência e da cultura" e também por meio "do intercâmbio de publicações, objetos de interesse artístico e científico, bem como [de] outros materiais de informação". objetivo era, com isso, "dar aos povos de todos os países acesso a material impresso e publicado, produzido por qualquer um deles". Pode-se ler também que um de seus propósitos e funções era "manter, ampliar e difundir o conhecimento por meio da conservação e proteção do patrimônio universal de livros, obras de artes, monumentos históricos e científicos e [por meio] da recomendação das convenções internacionais aplicáveis às nações interessadas" 27. Também encontramos nesse documento a defesa da cooperação com outras organizações intergovernamentais especializadas em assuntos da competência da Unesco, entre as quais o Conselho Internacional de Museus - ICOM.

Essa perspectiva foi sistematizada poucos anos depois, com o Programa de Assistência Técnica das Nações Unidas, elaborado em 1949. Nesse programa, estavam previstos, como formas de assistência técnica, missões de estudo ou de exploração, serviços de assessoramento, formação de professorado e de equipes de investigação e serviços de documentação ${ }^{28}$. $\bigcirc$ tema da cooperação entre países por meio da assistência técnica, entre outras modalidades, viria inclusive a ser proposto como "instrumento de promoção de desenvolvimento" e é digno de nota que os anos 1960 fossem declarados, pelas Nações Unidas, como "Decênio do Desenvolvimento"29.
23. Cf. Márcia Sant'Anna(2015, p. 206207).

24. Cf. Brasil (1980 p. 20); Maria Cecília Londres Fonseca (2005, p. 142).

25. Cf. Unesco (2006).

26. Ver Cecília Ribeiro Pereira (2012, p. 71-72).

27. Cf. Unesco (1945).

28. Ver Cecília Ribeiro Pereira (2012, p. 18-20).

29. Ibid. (p.220). 
30. Cf. Alicia Pérez Flores e Paulo César Miguez (2015, p.111).

31. Cf. Unesco, 1966.

32. Sobre esses debates, ver Claudia Feierabend Baeta Leal (2008, p.13-32).

33. Cf. Unesco, 1972a.

34. Entre as modalidades de assistência internacional previstas no texto da Convenção de 1972, encontra-se a "formação de especialistas em todos os níveis na área de identificação, proteção, conservação, valorização e reabilitação do patrimônio cultural e natural"; o fornecimento de equipamento que o Estado não possuísse nem tivesse condições de adquirir; empréstimos e subvenções; além de estudos dos problemas que afetassem o patrimônio natural e cultural, com vistas à sua proteção, conservação, valorização e reabilitação, e a "disponibilização de peritos, técnicos e mão-de-obra qualificada”, cf. Unesco (1972a).
Documentos posteriores produzidos pela Unesco, como relatórios das reuniões de seus conselhos, também abriam bastante espaço para as solicitações de assistência técnica dos Estados Membros junto a esse organismo, com especial destaque para a Declaração dos Princípios da Cooperação Cultural Internacional, proclamada pela Conferência Geral da Unesco na sua $14^{a}$ sessão, em 04 de Novembro de 1966.

Esse documento, ainda que não avançasse muito nas concepções e propostas lançadas em 1945, tampouco "em uma definição mais rigorosa do termo", estabelecia porém, "uma justificativa, um conjunto de valores e propósitos que norteariam sua ação" 30 . A declaração partia, assim, de algumas premissas da própria Constituição da Unesco, como a convicção de que a solidariedade moral e intelectual da humanidade deveria ser a base de construção da paz e de que a difusão da cultura e da educação contribuíriam para a justiça, a liberdade e a paz. Também afirmava a cooperação internacional como ação voltada a promover "o enriquecimento de todas as culturas", respeitando, porém, "o caráter diferenciado de cada uma delas" e a soberania dos Estados. Definia ainda que a cooperação cultural internacional - fosse bi- ou multilateral; regional ou universal - deveria ter como objetivos, entre outros, "o compartilhamento dos avanços cientíticos e dos benefícios resultantes destes em todas as parte do mundo"31, o que parece ir ao encontro da noção de assistência técnica que marcaram alguns dos programas articulados pela Unesco, entre os quais o envio de peritos a várias localidades. Tal ideia é reforçada no artigo $V$ da mesma declaração, em que se lê que a "A cooperação cultural é um direito e um dever para todos os povos e nações, os quais devem compartilhar com os outros seu conhecimento e habilidade".

Fora do escopo deste artigo, mas simultâneos à sistematização da noção de cooperação cultural internacional, nos anos 1960, são os debates referentes a gestação da ideia de patrimônio da humanidade, de defesa da proteção coletiva desse patrimônio, o que seria cristalizado em 1972, com a Convenção sobre a Proteção do Patrimônio Mundial, Cultural e Natural, elaborada no âmbito da Unesco ${ }^{32}$. Nesse documento, o destaque a cooperação e assistência técnicas ficava ainda mais evidente: a ênfase recaía sobre a noção de patrimônio como bens compartilhados por "toda a humanidade" e cuja responsabilidade cabia, consequentemente, a "toda a humanidade", dando-se especial destaque à assistência que deveria ser oferecida pela "coletividade internacional". Isso significava complementar - e estimular que várias nações também complementassem - as ações dos Estados nacionais no que concernisse a recursos financeiros, científicos e técnicos, principalmente nos casos em que faltassem, no âmbito do país em que o bem se encontrasse, os meios financeiros, técnicos e científicos necessários, notadamente "métodos científicos e modernos" ${ }^{33}$, para preservar e identificar esse patrimônio, assim como evitar a degradação e o desaparecimento do bem em questão ${ }^{34}$.

No que diz respeito aos contatos do Brasil, mais precisamente da DPHAN com a Unesco, essa cooperação concretizou-se, ainda em 1964, com a 
vinda ao Brasil de Paul Coremans, diretor do Real Instituto de Estudo e Conservação do Patrimônio Artístico, de Bruxelas, Bélgica. $\bigcirc$ sentido atribuído pela imprensa brasileira a essa missão caracterizou-a, primordialmente, como uma iniciativa da Unesco, sendo descrita como resultado de sua preocupação "com a situação de abandono e de desprezo das coisas da cultura brasileira" ${ }^{\prime 3}$. No entanto, é preciso relativizar o protagonismo exclusivo atribuído à organização.

papel da Unesco foi certamente determinante para a realização da missão, que teria sido proposta pelo diretor de assuntos culturais desse organismo, Lourival Gomes Machado, prevendo duas possibilidades de visita, conforme explicou a arquiteta Cecília Ribeiro Pereira ao analisar a correspondência trocada entre o diretor e Rodrigo Melo Franco de Andrade:

A missão de Coremans no Brasil foi programada por Lourival Gomes Machado e previa duas possibilidades: na primeira, seriam privilegiados os "programas [que] se reporta[vam] à preservação e à estabilização de um sítio cultural dado, como Ouro Preto, ou um monumento histórico importante"; a segunda seria orientada para "a criação e o desenvolvimento de um laboratório nacional", que deveria ser encarregado "dos trabalhos científicos e técnicos que dizem respeito à preservação dos bens culturais" 36 .

Orelatório elaborado por Coremans detalha exatamente sua avaliação dos laboratórios da DPHAN, as visitas a edificações antigas do sítio urbano de Ouro Preto e o encaminhamento de "propostas para sua conservação" e de "um programa para o futuro", como se lê no documento datado de maio de 1964 e com cópia disponível no Arquivo Central do Iphan/Seção Rio de Janeiro (daqui em diante, $\mathrm{ACl} / \mathrm{RJJ}^{37}$. A descrição com que Coremans inicia a análise dos problemas enfrentados pela DPHAN vai bem ao encontro das preocupações sobre os problemas urbanos já detalhados pela Recomendação de Paris de 1962 e experimentados pelo Brasil pelo menos desde a década de 1950: o perito belga descreve o Brasil como uma "colmeia zumbidora"38, em menção a obras de construção civil, principalmente rodovias voltadas para o interior do país; também procurou mostrar sua preocupação em relação ao fato de tais obras parecerem "menosprezar o passado", sublinhando, porém, os esforços que a DPHAN empregava em defesa do patrimônio histórico e artístico, com especial destaque à atuação do diretor Rodrigo Melo Franco de Andrade, descrito por Coremans como a própria base e estrutura da diretoria ${ }^{39}$.

No entanto, é interessante relativizar o protagonismo exclusivo atribuído à Unesco no estabelecimento das missões de peritos ao Brasil a partir dos anos 1960. Em seu texto, Coremans deixou clara a intervenção das autoridades brasileiras em sua visita, mencionando o contato com elas e o interesse em relação à sua análise e às propostas. Descreveu a visita como "missão de orientação que, bem preparada pelas partes interessadas, tenta propor bases válidas a serem acompanhadas por adaptações posteriores." 40 . Além de sublinhar a participação do então diretor da DPHAN, Rodrigo Melo Franco de Andrade, no próprio detalhamento da missão, o perito belga também listou, no item "Agradecimentos"
35. "UNESCO pediu há dois anos defesa do nosso patrimônio histórico" $O$ Globo, 21/12/1966.

36. Cf. Cecília Ribeiro Pereira (2012,, p. 730.

37. Ver Paul Coremans (1964).

38. Ver Paul Coremans (1964, p. 4).

39. Sobre a missão de Paul Coremans ao Brasil, assim como sua produção como perito da Unesco em missões ao longo da década de 1960, ver Claudia Feierabend Baeta Leal (2011).

40. Ver Paul Coremans (1964). 
41. Cf. Cecília Ribeiro Pereira (2012, p. 114). Vale destacar que, conforme destaca Pereira, essa missão não resultou em relatório, diferentemente das demais citadas no parágrafo.

42. Ver Michel Parent (2008); Fréderic de Limburg Stirum (1968); Pierre Habib (1979); Graeme Shankland (s.d.; 1969); A. E. Viana de Lima (1970;1972; 1973; 1973; 1978 a e b).

43. Localização topográfica: AA01/ M066/ P05/ Cx. 0059/ P190 e 191 e AA01/ M066/ P05/ Cx. 0060/P 192, Arquivo Central do IPHAN - Seção RJ. de seu relatório, os encontros e orientações que teve a respeito de sua missão, mencionando os contatos com autoridades brasileiras mesmo antes de sua partida para o Brasil e durante toda a visita.

À missão de Coremans, seguiram-se outras: Michel Parent, inspetor do Serviço Principal de Inspeção dos Monumentos e de Inspeção de Sítios na França, enviado como especialista pela Unesco no âmbito do programa Turismo Cultural, visitou 35 cidades brasileiras em missões em 1966 e 1967; Frédéric de Limburg Stirum, conde belga e arquiteto pela École Speciale de Architecture, em Paris, esteve em Paraty, no estado do Rio de Janeiro, em 1967; Ali Vrioni, que substituiu Lourival Gomes Machado na direção de Assuntos Culturais da Unesco, visitou Rio de Janeiro, Salvador e Brasília entre janeiro e fevereiro de 1968, com vistas a "acertar questões relacionadas a projetos prioritários" estabelecidos entre Unesco e DPHAN para missões ao Brasil ${ }^{41}$; o inglês Graeme Shankland, arquiteto e urbanista do Departamento de Urbanismo do Conselho Municipal de Londres, Inglaterra, foi a Salvador em outubro de 1968; nas décadas de 1960 e 1970, Alfredo Evangelista Viana de Lima, arquiteto pela Escola Superior de Belas Artes do Porto, em Portugal, visitou o Brasil várias vezes, dirigindo-se às cidades de Ouro Preto, em Minas Gerais, São Luís e Alcântara, no Maranhão, Laranjeiras e São Cristóvão, no estado de Sergipe, Marechal Deodoro e Penedo, em Alagoas, entre outras; entre maio e junho de 1979, o doutor em engenharia e diretor do Laboratório de Mecânica de Sólidos da Escola Politécnica de Paris, Pierre Habib, veio a Olinda e Ouro Preto para visitar e examinar suas igrejas. Todas essas missões resultaram em relatórios cujas cópias encontram-se no $\mathrm{ACl} / \mathrm{RJ}$ e na Biblioteca Noronha Santos, também no Rio de Janeiro ${ }^{42}$.

Para além desses relatórios, O $\mathrm{ACl} / \mathrm{RJ}$ guarda uma importante documentação referente a essas missões, da qual se destacam aqui as pastas intituladas "IPHAN/Assunto Internacionais/ UNESCO - Plano de Preservação de Conjuntos Urbanos"43. Trata-se de um vasto conjunto de cartas, ofícios, memorandos, telegramas, requerimentos, impressos, recortes de jornais, curricula, descrições de tarefas, programas de simpósios e congressos que informam sobre os peritos, sobre as negociações e arranjos necessários para sua vinda; ajudam a entender os propósitos, motivações, discussões, benefícios relacionados às missões desses consultores, assim como os debates suscitados - interna e externamente à DPHAN e também à Unesco - pela escolha das cidades e pela sua estadia, além de ajudar a compor a narrativa e a história da preservação e de seus atores em níveis nacional e internacional. Evidenciam as negociações em que tais instituições estiveram envolvidas para estabelecer, em conjunto, o escopo de tais missões e destacam as posturas informadas, interessadas e estratégicas por meio das quais o Brasil, em largo sentido por meio da DPHAN, conquistou receber os consultores e também por meio das quais se apropriou de tais missões.

É possível notar, por exemplo, no estudo dessa documentação, que o contato da diretoria com a Unesco esteve fortemente envolvido com os programas 
de assistência técnica oferecidos por esse organismo aos chamados "países em desenvolvimento", privilegiando questões referentes ao patrimônio cultural e ao turismo. Nesse sentido, destacam-se os programas de incentivo ao Turismo Cultural e os Country Programmes [Programas para países], que visavam à "preservação e desenvolvimento do turismo para uma série de monumentos históricos, bairros históricos de cidades e sítios arqueológicos em aproximadamente 30 (trinta) países"44. Tal assistência dava-se por meio da elaboração de documentos e pareceres técnicos, envio de peritos, treinamento de pessoal, projetos promocionais de monumentos, museus e conjuntos arquitetônicos, além de envolver, conforme entendimento da própria DPHAN, "concurso financeiro de estabelecimento de crédito internacional, sob responsabilidade da Unesco, para conservação e recuperação de monumentos e proteção da natureza nos territórios dos Estados membros" 45 . Nota-se que, para além do óbvio interesse na preservação do patrimônio nacional, que constituía a própria missão e responsabilidade da diretoria, a parceria com a Unesco apontava para várias possibilidades de assistência, fosse de recursos financeiros, fosse de provisões técnicas e intelectuais para sua tarefa, e também de divulgação interna e externa das condições enfrentadas e ações conduzidas pelo órgão brasileiro de preservação, com dados e informações disponibilizados exatamente por este órgão. ${ }^{46}$

Sem de forma alguma questionar a autonomia de tais consultores em suas avaliações, o que se pretende sugerir aqui é entendê-las como um produto negociado entre as partes, em que figurasse tanto a perspectiva da diretoria avaliada como aquela do organismo avaliador. A análise da documentação já citada e, principalmente, dos relatórios elaborados pelos peritos permite supor que tais avaliações parecem tanto dar sugestões ao corpo técnico da DPHAN sobre como aprimorar seus serviços, como informar a Unesco sobre as condições de trabalho da diretoria. E mais: reforçar internamente tais condições, de forma a promover a valorização das iniciativas da diretoria junto ao governo brasileiro e pleitear incremento dos recursos disponíveis junto aos órgãos cabíveis.

A documentação guardada pelo $\mathrm{ACl} / \mathrm{RJ}$, notadamente os relatórios dos consultores, ajuda a entender em que chaves elaboraram e inseriram suas sugestões e como elas foram apropriadas pela DPHAN.

Paul Coremans, por exemplo, centrou-se, principalmente, nas questões voltadas à conservação. Além de defender a importância de um amplo inventário fotográfico, sem o qual, argumentou, os tombamentos e a conservação dos bens não seriam possíveis, reforçou a importância da colaboração entre as ciências exatas e humanas - leia-se física e química, de um lado; história da arte do outro - na orientação das pesquisas de conservação; e da busca de assistência técnica junto ao Real Instituto de Estudo e Conservação do Patrimônio Artístico - IRPA belga, à Unesco, ao ICOM, ao Centro da Unesco em Roma, com elogios à participação de um técnico da DPHAN, Jair Afonso Inácio, como bolsista do IRPA entre 1961 e 1962, e defendendo a participação de mais técnicos da DPHAN nos cursos de treinamento oferecidos pela instituição que então dirigia ${ }^{47}$.
44. Cf. Unesco (1972b, tradução da autora).

45. Cf. ofício de Rodrigo Mello Franco de Andrade ao Ministro da Educação e Cultura Moniz Aragão, em 20 de outubro de 1966. ACI/ RJ, AA01/ M066/ P05/ Cx. 0059/ P190.

46. Ver Claudia Feierabend Baeta Leal (2008, p. 30).

47. Ver Claudia Feierabend Baeta Leal (2011). 
48. Vale destacar a coincidência entre os bens referidos por Parent $\mathrm{e}$ aqueles protegidos pela DPHAN: dos mais de 220 bens nominalmente citados em seu relatório, entre conjuntos, edificações e sítios espalhados pelas cidades visitadas, $70 \%$ eram tombados pela DPHAN à época de sua missão, e muitos outros estavam incluídos na proteção a conjuntos mais amplos. Na publicação do Iphan que traz a tradução e a reprodução de seu relatório, encontra-se uma tabela com os bens referidos por Parent e sua situação em relação à proteção oferecida pela DPHAN à época e indicação de proteções posteriores. Ver Michel Parent (2008, p. 327338).

49. Ver Marcia Sant'Anna (2015, p 207).

50. Cf. Michel Parent (2008, p. 61).

51. Ver Lia Motta; Maria Beatriz Resende Silva (1998, p. 13).

52. Ver Marcia Sant'Anna (2015, p. 207-208).

53. Cf. Lia Motta e Analucia Thompson (2010, p. 39).

54. Cf. Lia Motta e Analucia Thompson (2010, p. 39-40).

55. Ver Michel Parent (2008).
Destacam-se também, ainda que de forma não tão sistematizada quanto apareceria nos relatórios dos que o sucederam, seus argumentos em prol do fomento ao turismo.

O relatório de Michel Parent, que descreve principalmente sítios e bens já reconhecidos e protegidos pela DPHAN ${ }^{48}$, permanece na historiografia sobre a preservação no Brasil como marco de mudanças do campo: segundo Marcia Sant'Anna, o relatório teria passado a "constituir a base de toda a atuação futura não só do IPHAN mas de todo o governo federal com relação ao patrimônio", com sua ênfase no planejamento urbano e no aproveitamento turístico ${ }^{49}$. $O$ texto é também bastante enfático sobre a importância de inventários pormenorizados para a prática da preservação, e traz elogios ao que descreveu como "inventário monumental, extremamente minucioso, relativo a mais de mil edifícios que permanece como o melhor instrumento desse gênero em todo o continente" 50 , ainda que estivesse se referindo, especificamente, aos estudos realizados pelos técnicos da diretoria para embasar as escolhas e os processos envolvidos nos tombamentos, uma vez que, nessa instituição, os inventários só se tornaram expressivos como prática institucional a partir da década de $1980^{51}$. A questão, porém, era importante para $O$ inspetor francês, que até sugeriu dados para constar em uma possível ficha de inventário com vistas à uma documentação pormenorizada dos bens e sítios, e ao estabelecimento de áreas de proteção mais amplas em alguns sítios históricos.

Márcia Sant'Anna chama atenção para a influência da Lei Malraux, promulgada na França em 1962, no entendimento expresso por Parent em seu relatório, notadamente na ênfase que dá ao planejamento urbanístico de conjunto, baseado em um forte controle administrativo, ainda que descentralizado; à revitalização global dos sítios, com a identificação das construções cuja restauração fosse mais urgente e a reconversão dos usos desses edifícios; e à preservação da natureza, principalmente por meio da determinação de áreas non aedificandi e de reservas naturais ${ }^{52}$. Também estaria presente em seu relatório a valorização das tradições e manifestações culturais das diversas regiões brasileiras, do conhecimento das potencialidades turísticas de cada local e do desenvolvimento da infraestrutura viária e hoteleira oferecida para fins turísticos.

Motta e Thompson, por sua vez, destacam a perspectiva que Michel Parent evidencia em seu relatório, "baseada na experiência europeia do planejamento urbano e territorial, assim como na Carta de Veneza, de 1964, associando as cidades e os monumentos à paisagem e ao contexto de sua implantação." ${ }^{3} 3$. Segundo as autoras, Parent elaborou propostas distintas para as cidades de acordo com seu porte, mas sempre com grande ênfase nas questões urbanísticas, na valorização da proteção de conjuntos, e na proposta da Carta de Veneza de entender monumento como sendo "inseparável da história de que é testemunho e do meio em que se situa" 54. Também fazem menção à elaboração, pelo perito belga Fréderic de Limburg Stirum, de um plano diretor para Parati que foi inserido no estudo de Parent sobre aquela cidade ${ }^{55}$. 
Motta e Thompson discutem também como o consultor Graeme Shankland, que esteve em Salvador em 1968, expõe seu entendimento da capital baiana, valorizando tanto a inserção da cidade na paisagem natural, como as manifestações culturais que testemunhou em sua visita ${ }^{56}$. Marcia Sant'Anna, por sua vez, apresentou o plano de renovação proposto pelo perito inglês - que seria responsável por "grandes projetos turísticos" - como baseado nas indicações de Michel Parent, mas "prevendo a substituição da população economicamente incapaz e a elevação do padrão habitacional"57.

Paralelamente a identificar as noções expressas pelos consultores em seus relatórios e demais documentos produzidos sobre suas missões e os debates nacionais e internacionais sobre a preservação do patrimônio - com destaque para o entendimento dos bens em seus contextos, sua relação com a paisagem, a natureza e as manifestações culturais, o planejamento urbanístico para preservação e a proteção de conjuntos -,destaca-se a importância de outro tema para os trabalhos dos consultores europeus e também para as práticas e estratégias institucionais brasileiras: o turismo.

No que concerne ao patrimônio, o tema do turismo aparece marcado, nos anos 1960, por preocupações envolvendo a articulação entre desenvolvimento e preservação. Ainda que a noção de interesse público estivesse, nacional e internacionalmente, desde pelo menos a década de 1950, atrelada ao desenvolvimento econômico, entendia-se também que o "bem-estar de todos os povos" estava relacionado à preservação dos bens culturais, como se lê na Recomendação de Paris, de $1968^{58}$. Cabia, portanto aos governos, igualmente, "assegurar a proteção e a preservação da herança cultural da humanidade" e "promover o desenvolvimento social e econômico" 59, o qual, porém, notavelmente, representava ameaças aos bens culturais e naturais, fosse por impactos nocivos diretos com obras de infraestrutura públicas ou privadas, crescimento urbano, disseminação de tecnologias agrícolas impactantes, industrialização; fosse ainda pela desvalorização dos aspectos culturais envolvidos na preservação do patrimônio (por meio da especulação imobiliária, por exemplo).

Tornava-se premente, portanto, enfrentar tais ameaças e encontrar formas de, se não "harmonizar", ao menos compatibilizar preservação e desenvolvimento. A apropriação turística dos bens culturais aparecia nesse sentido nos documentos internacionais tratados acima e foi sendo, nesses anos 1960, lentamente incorporada às discussões da DPHAN.

Para além de uma bibliografia especificamente voltada para o tema da relação entre turismo e preservação do patrimônio, como o são as teses de Leila Bianchi Aguiar ${ }^{60}$ e de Cecília Ribeiro Pereira ${ }^{61}$, há toda uma documentação dos anos 1960 que traz vivamente tal discussão. Já foram mencionadas aqui as Recomendações de Paris, de 1962 e 1968, e as Normas de Quito, de 1967, e suas ênfases na preocupação com os impactos do desenvolvimento sobre o patrimônio. Todos os três documentos, com ênfases distintas, trabalham com o entendimento do turismo como uma atividade que compatibilizaria ou harmonizaria
56. Ver Lia Motta e Analucia Thompson (2010, p. 42).

57. Cf. Marcia Sant'Anna(2015, p. 210).

58. Ver Isabelle Cury (2004, p. 124).

59. Ibidem.

60. Ver Leila Bianchi Aguiar (2006).

61. Ver Cecília Ribeiro Pereira (2012). 
62. Cf. Isabelle Cury (2004, p. 82).

63. Ibid.(p. 124).

64. Ibid. (p. 113)

65. Para detalhes dos textos referidos, ver Claudia Feierabend Baeta Leal (2008, p. 15-19).

66. A cópia do relatório do Comité d'experts internationaux pour la mise em valeur du patrimoine culturel par le développement économique - Rapport final (UNESCO, 1968), que fora enviada pelo Ministério das Relações Exteriores à DPHAN em junho de 1968, conta com anotações, à margem, da técnica Lygia Martins Costa, que deu ciência de seu recebimento e observou que o documento era "Da maior importância para a DPHAN, uma vez que lhe abre caminho para uma ação bem mais efetiva".

67. UNESCO, 1968. as necessidades de desenvolvimento social e econômico e preservação do patrimônio. Na citada recomendação de 1962, por exemplo, os órgãos responsáveis pelo fomento ao turismo nos Estados Membros foram incluídos entre outros organismos "envolvidos com a proteção das paisagens e sítios" e "encarregados da proteção da natureza"62. O documento de 1968 traz ainda em seus "Considerandos" a importância da exposição adequada dos bens culturais ao "turismo nacional e internacional" como forma de contribuir "poderosamente para o desenvolvimento social e econômico dos países"63. As Normas de Quito, por sua vez, são bastante enfáticas na sua defesa de se entenderem e explorarem "os monumentos em função do turismo" 64 , não apenas como atrativos para este último, mas também como forma de assegurar sua salvaguarda. Além disso, fazem referência a uma série de reuniões internacionais que haviam focado na importância econômica do patrimônio cultural e, mais especificamente, no turismo, buscando consolidar uma visão positiva da apropriação turística dos bens culturais ${ }^{65}$.

Em janeiro de 1968, em Túnis, na África, a reunião do Comitê de peritos internacionais para a valorização do patrimônio cultural em prol do desenvolvimento econômico - que contou com a presença, entre os especialistas, de Michel Parent, recém-retornado de sua missão ao Brasil - tirou uma série de recomendações que foram organizadas em relatório publicado em maio de 1968. Nesse documento, cujo exemplar disponível no ACl/RJ encontra-se com anotações da técnica da DPHAN, Lygia Martins Costa ${ }^{66}$, os temas abordados nas Normas de Quito foram mantidos: de um lado, o destaque aos perigos que ameaçavam conjuntos, monumentos e sítios, resultantes tanto da "falta de meios para preserválos" quanto "da industrialização progressiva e dos grandes trabalhos públicos"; de outro, a ênfase no estreitamento da relação entre as exigências do desenvolvimento econômico e a valorização dos bens culturais a partir da perspectiva do turismo.

Desse mesmo relatório, destacam-se os itens 3, 4 e 5 de sua ordem do dia, que buscaram, mais especificamente, relacionar sítios e monumentos ao desenvolvimento e indicaram programas culturais voltados para $\circ$ progresso econômico com base no desenvolvimento do turismo cultural. $\bigcirc$ comitê reunido procurou frisar, nesse sentido, que a atração dos conjuntos, dos monumentos e dos sítios, assim como das instituições culturais era, então, "uma das motivações mais importantes do turismo cultural". E continuava: "Este [o turismo cultural] constitui, sob suas diversas formas, um fator essencial do desenvolvimento econômico do país". Também buscou chamar a atenção para os problemas apontados pelos peritos, "notadamente [por] aqueles vindos de países em desenvolvimento", e para formas de assistência prestada pela Unesco, tais como o envio de peritos que poderiam "ajudar os governos a definir e estabelecer os programas, particularmente aqueles concernentes ao turismo, que devem integrar-se aos planos de desenvolvimento gerais dos países" 67 .

Os relatórios dos consultores que estiveram no Brasil na década de 1960 também destacaram a importância do turismo em sua dupla relação com o desenvolvimento e a preservação do patrimônio, ainda que esse tema não tenha 
sido, para a DPHAN, desde o início da parceria com a Unesco, o ponto central. A documentação sob a guarda do $\mathrm{ACl} / \mathrm{RJ}$ permite acompanhar, por exemplo, os diversos sentidos que essa atividade assumiu no âmbito da DPHAN desde meados da década de 1960, quando aqui, aparentemente, ainda se conhecia pouco sobre os programas que visavam o incentivo a essa atividade.

A vinda de Michel Parent ao Brasil teria se enquadrado exatamente nesse contexto de ênfase na relação entre turismo, desenvolvimento econômico, preservação e valorização do patrimônio cultural; da busca de cooperação entre os dois organismos voltados para a preservação do patrimônio cultural - DPHAN e Unesco -; e de esforços por parte do governo brasileiro nesse sentido:

Plano de incentivo ao chamado Turismo Cultural, importando em concurso financeiro de estabelecimento de crédito internacional, sob responsabilidade da Unesco, para conservação e recuperação de monumentos e proteção da natureza nos territórios dos Estados Membros. Esse plano foi adotado por proposta feliz do Diretor Geral [da Unesco] René Maheu (acrescentado por sugestão do Embaixador Carlos Chagas). Pleiteamos a aplicação dele ao Brasil. Se a Conferência Geral tiver que incluir no orçamento recursos destinados a favorecê-lo, há grande conveniência de que a Delegação Brasileira, sob sua presidência, apóie a medida ${ }^{68}$

No que diz respeito ao recurso ao "plano de incentivo ao chamado Turismo Cultural", e recuperando a discussão acima, o peso dado à atividade turística pela Unesco parece ser superior àquele atribuído a tal atividade pela DPHAN. Os documentos sugerem maior interesse, por parte dessa diretoria, pela assistência financeira e técnica envolvidas no plano de incentivo e que poderia ser utilizada em prol da "conservação e recuperação de monumentos e proteção da natureza", do que propriamente pela criação de relações mais próximas entre o turismo e o patrimônio cultural brasileiro. Os contatos estabelecidos pela DPHAN com a Unesco buscavam, é claro, parceria com o principal organismo internacional de proteção do patrimônio e seu aval técnico, mas também havia a busca por assistência financeira, que poderia vir por meio de diversos programas. É o que se pode notar, por exemplo, em memorando do então chefe da Divisão de conservação e restauração da DPHAN, Renato Soeiro, arquiteto, dirigido a Rodrigo Melo Franco de Andrade, em 1966, informando-o sobre os programas oferecidos pela Unesco, por meio dos quais poderiam "obter recursos para nossa participação"69. Sua lista incluía o programa de Recuperação de Recursos Naturais, que ajudaria aquela Diretoria a enfrentar "a ameaça das BRs", e o plano de Incremento ao Turismo, programa que oferecia "medidas que beneficiariam Ouro Preto, Parati e áreas tombadas como Salvador", sem maiores destaques a este último ${ }^{70}$. $\bigcirc$ próprio chefe da delegação permanente do Brasil junto à Unesco, o embaixador Carlos Chagas Filho, ao informar o diretor da DPHAN sobre a medidas que tomara em relação "ao programa de proteção do Patrimônio Histórico", escreveu que conseguira uma missão daquele organismo para o Brasil "sob a denominação mais ou menos esdrúxula de 'turismo
68. Cf. Ofício de Rodrigo Melo Franco de Andrade. a Moniz Aragão, Ministro da Educação e Cultura, em 20/10/1966. ACI/RJ, AA01/ M066/ P05/ Cx. 0059/ P190.

69. Cf. Memorando de Renato Soeiro a Rodrigo Melo Franco de Andrade, em 21/06/1966. ACI/RJ, AA 01/M066/P05/Cx. 0059/P. 0190.

70. Idem. 
71. Cf. Carta de Carlos Chagas Filho a Rodrigo Melo Franco de Andrade, em 21/06/1966. Arquivo Central do IPHAN/ Seção Rio de Janeiro, AA 01/ M066/P05/Cx. 0059/P. 0190.

72. Vale também mencionar que as referências que a direção da DPHAN e seus técnicos fizeram sobre a missão de Parent sublinhavam, principalmente, objetivos técnicos, de avaliação dos trabalhos realizados por aquela diretoria, sem maiores menções à questão do turismo. Ver, por exemplo: ofício de Rodrigo de Melo Franco de Andrade a John M. Howe, chefe da Missão da Unesco no Brasil, em 22/11/1966; ofício de Rodrigo de Melo Franco de Andrade a Ali Vrioni, diretor do Departamento Cultural da Unesco, 05/12/1966. ACI/ RJ, AA 01/M066/P05/Cx. 0059/P. 0190

73. Ver Leila Bianchi Aguiar (2006).

74. Ver Marcia Sant'anna (2015, p. 207).

75. Ofício de Renato Soeiro a Nestor dos Santos Lima, Ministro das Relações Exteriores, em 14/11/1968. ACI/RJ, AA 01/M066/P05/Cx. 0059/P. 0190.

76. Cf. A Chave... (1972); Carta... (1972).

77. Ver Leila Bianchi Aguiar (2006, p. 130).

78. Cf. Claudia Feierabend Baeta Leal (2011).

79. Ver Claudia Feierabend Baeta Leal (2008); Lia Motta e Analucia Thompson (2010); Cecilia Ribeiro Pereira (2012); Marcia Sant'Anna (2015, p. 207-210).

80. Ver Lia Motta e Analucia Thompson (2010); Marcia Sant'Anna (2015, p. 210).

81. Ver Cecília Ribeiro Pereira (2012). cultural'."71. A ênfase, portanto, estava na assistência tout court; a questão do turismo parecia então constar como uma porta de acesso ao organismo e a seus programas de assistência ${ }^{72}$.

turismo, porém, não era um assunto inédito no Brasil. Leila Bianchi Aguiar apresentou iniciativas voltadas à atividade, fosse de empresários ou dos setores públicos, desde as primeiras décadas do século $X X^{73}$. Já na DPHAN, o tema do turismo foi ganhando importância no final da década de 1960, e não é demais afirmar que isso de se deveu às parcerias estabelecidas com a Unesco nesse período, fortalecendo-se com o relatório de Michel Parent, que teria sugerido as bases para as ações futuras da diretoria ${ }^{74}$. É exemplo disso o ofício enviado por Renato Soeiro, então diretor da DPHAN, ao Ministro das Relações Exteriores, Nestor dos Santos Lima, em 1968, no qual sublinhou a aproximação entre os objetivos da DPHAN e o tema da reunião do Comitê de peritos internacionais para a valorização do patrimônio cultural (cujo relatório final foi analisado acima), que fora a "valorização do nosso patrimônio cultural e sua integração nos planos de turismo e desenvolvimento econômico do país"75. Soeiro também esteve presente no Congresso Extraordinário Interamericano do Turismo, entre 18 a 25 de agosto de 1972, no Rio de Janeiro, durante o qual o diretor da Embratur, Paulo Manoel Protasio, teria mostrado interesse em firmar uma cooperação entre essa empresa e a Unesco, ao mesmo tempo em que manifestou a intenção de entrar em contato com Soeiro para "estabelecer, com ele, um programa de cooperação que permitirá à Embratur apoiar e estimular os projetos atualmente desenvolvidos pelo patrimônio"76. Ainda que ações relacionadas ao turismo cultural envolvendo bens protegidos pela DPHAN começassem então a se esboçar, o contato entre essa diretoria e a Embratur estreitar-se-ia efetivamente em 1975, data da primeira ação conjunta estre as duas instituições, com o Programa Integrado de Reconstrução das Cidades Histórica, o $\mathrm{PCH}^{77}$.

Nesse sentido, é importante levar em conta como as resoluções da Unesco voltadas para o turismo foram fazendo parte do universo de possibilidades para ajudar na preservação, no desenvolvimento e no aproveitamento do patrimônio cultural brasileiro, principalmente por meio dos contatos estabelecidos pela DPHAN com os peritos enviados por aquele organismo ao Brasil. A leitura dos relatórios produzidos durante as missões dos consultores contribui para entender a proposição do turismo como atividade que poderia atender questões referentes à preservação do patrimônio histórico e artístico nacional, como já foi destacado em análises dos textos de Paul Coremans $^{78}$, Michel Parent ${ }^{79}$, Graeme Shankland ${ }^{80}$ e Viana de Lima ${ }^{81}$, principalmente, no que diz respeito a apropriação, promoção e possível sustento do patrimônio pelo turismo.

Entre esses relatórios, destaca-se, especialmente, o produzido por Michel Parent sobre a visita ao Brasil em 1966 e 1967 - Proteção e valorização do patrimônio cultural brasileiro no âmbito do desenvolvimento turístico e econômico. 
título do relatório, aliado à importância que o turismo vinha assumindo no contexto internacional de preservação do patrimônio, reforça o espaço destinado ao tema do turismo. Essa atividade foi descrita, logo nas primeiras linhas do texto de Parent, como uma importante possibilidade de planejamento e desenvolvimento global. Seu enfoque buscou sublinhar, por um lado, a potencialidade que a atividade turística representava para um país em desenvolvimento e com as virtudes com que essa nação contava. É interessante perceber que a noção de patrimônio apresentada por Parent em seu relatório não se limitava ao patrimônio edificado, incluía a natureza, as tradições, as manifestações culturais, o que aparece também em sua proposta de desenvolvimento do turismo como um processo de intercâmbio cultural, como "compreensão mútua entre os povos e o desenvolvimento e salvaguarda de suas culturas específicas", beneficiada, no Brasil, segundo o consultor, pela diversidade do patrimônio, pela amenidade do clima e pela "disposição inata do brasileiro de ser um anfitrião". Por outro lado, chamou a atenção para o pouco desenvolvimento que tal atividade tinha até então no Brasil, e defendeu seu fomento na perspectiva da valorização relação entre turismo e a proteção do patrimônio:

\footnotetext{
O turismo pode, com certeza, constituir uma das fontes do futuro desenvolvimento da renda nacional e fornecer um álibi econômico aos esforços consideráveis que devem ser feitos se quisermos salvaguardar o vasto patrimônio cultural que está há muito tempo em perigo, mas cuja ruína brevemente será irreversível82.
}

Vale, no entanto, destacar os trechos do relatório de Parent em que ele mostrou ciência em relação aos possíveis danos que o turismo poderia causar ao se aliar aos "demais fatores de degradação e, tanto material como psicologicamente, contribuir para degradar os bens naturais e culturais e, por conseguinte, negar-se a si próprio". Para tanto, o perito sugeria que a atividade fosse acompanhada e controlada - seus elogios à criação da Empresa Brasileira de Turismo (Embratur), em 1966, foram essencialmente nesse sentido - e que a rentabilidade do turismo não fosse o único critério a ser utilizado como medida do sucesso da atividade.

Na perspectiva que a Unesco ajudava a construir no âmbito da DPHAN, na qual o turismo aparecia com especial relevo, patrimônio e desenvolvimento uniam-se em um terreno se não harmônico, ao menos compatível.

No entanto, as políticas voltadas à preservação de bens protegidos por essa diretoria e de uma diversidade de outros bens em perigo estavam em cheque desde pelo menos o final da década de 1950 - entre outras razões, pelas verbas escassas ao campo da cultura ${ }^{83}$, da construção maciça de rodovias, da crescente urbanização e consequente crescimento vertiginoso das cidades ${ }^{84}$. Essa revisão de diretrizes incluía discussões sobre quão eficazes e apropriados eram os procedimentos e instrumentos então disponíveis frente ao desenvolvimento, aos interesses econômicos e ao crescimento das cidades. É sobre algumas dessas discussões que este artigo se debruçará a seguir.
82. Cf. Michel Parent (2008).

83. Lia Calabre, op. cit., p. 63.

84. Marcia Sant'Anna, op. cit., p. 205. 
85. Cf. Lei $\mathrm{n}^{\circ} 3924$, de 26 de julho de 1961. Dispõe sôbre os monumentos arqueológicos e préhistóricos. Diário Oficial da União - Seção 1 - 27/7/1961, Página 6793.

86. Estava prevista na legislação brasileira a exploração econômica de sítios arqueológicos, como destaca Regina Coeli Pinheiro da Silva, ao indicar o parágrafo $1^{\circ}$ do artigo $1^{\circ}$ do Código de Minas - DecretoLei $\mathrm{n}^{\circ} 1985$, de 20 de janeiro de 1940, que considerava jazida "toda massa de substância mineral ou fóssil existente no interior ou na superfície da terra e que apresente valor para a indústria”. Cf. Regina Coeli Pinheiro da Silva (1996, p. 17).

87. Ver Lucieni de Menezes Simão (2000, p. 430 e 431); Regina Coeli Pinheiro da Silva (1996, p. 19); Mario Ferreira de Pragmácio Telles (s/d)

88. Cf. Decreto-Lei $\mathrm{n}^{\circ} 25$, de 30 de novembro de 1937 , capítulo I, art. $1^{\circ}$.

89. Sobre como a literatura discute a efetividade do Decreto-Lei $n^{\circ}$ 25/1937 para proteção dos bens arqueológicos, ver Sonia Rabello (2009); Regina Coeli Pinheiro da Silva (1996); Mario Ferreira de Pragmácio Telles (s/d).

90. Ver Tânia Andrade de Lima (1987, p. 24-25).

91. Cf. Lucieni de Menezes Simão (2000).

92. Cf. Mario Ferreira de Pragmácio Telles (s/d).

93. Idem. Esse argumento é, no entanto, rebatido por Regina Coeli Pinheiro da Silva (1996).

\section{$\bigcirc$ patrimônio frente ao desenvolvimento}

Mesmo com as possibilidades que a apropriação turística do patrimônio representava, o perigo de destruição, exploração predatória, desaparecimento e descaracterização do patrimônio forçava o campo da preservação a pensar formas de como resistir aos avanços do desenvolvimento ou mitigar seus impactos. Discussões relevantes dos anos 1950 e que perpassaram os 1960 envolveram, principalmente, os sítios e bens arqueológicos, o patrimônio natural e os conjuntos urbanos, bens ainda não considerados nas ações mais tradicionais da DPHAN e que pareciam especialmente vulneráveis aos interesses econômicos e políticas desenvolvimentistas. Entender as iniciativas da DPHAN para abrangê-los possibilita acessar as ênfases das políticas de patrimônio desse período.

$\bigcirc$ tema da proteção aos bens arqueológicos é especialmente interessante entre aqueles que ganharam destaque nos anos 1960 por evidenciar discussões referentes a como resistir aos avanços dos interesses econômicos sobre bens de interesse patrimonial, como também por apresentar iniciativas de preservação que não emanaram, nem exclusiva nem primordialmente, da Diretoria do Patrimônio, mas que resultaram de articulações paralelas às ações da DPHAN, entre as quais a promulgação da Lei n 3924, de 26 de julho de 1961, conhecida como "Lei da Arqueologia", é das mais marcantes.

Os esforços que pautaram o processo de elaboração da lei que "dispõe sobre os monumentos arqueológicos e pré-históricos" 85 datam já da década de 1950, quando ficaram especialmente evidentes as preocupações com a exploração econômica a que muitos sítios arqueológicos, considerados "jazidas"86, estavam submetidos, especialmente sambaquis e grutas ${ }^{87}$. Tais preocupações atingiram diretamente o instrumento então utilizado para a proteção dessa tipologia de bens: - Decreto-Lei n² 25/1937 e as medidas que criava para a proteção dos "bens móveis e imóveis" que apresentassem "excepcional valor arqueológico"88. Passouse a debater, então, a efetividade desse instrumento tanto para resguardar tais bens da exploração econômica, como também para proteger a totalidade dos bens arqueológicos - ou "monumentos arqueológicos ou pré-históricos de qualquer natureza", como consta do texto da lei ${ }^{89}$.

A literatura disponível trata do empenho do presidente Jânio Quadros, empossado em janeiro de 1961, para sua aprovação90. Também aponta como motivação para a promulgação de uma lei nacional específica para tal categoria de bens as discussões científicas a respeito do valor cultural dos sítios arqueológicos ${ }^{91}$, - que conflitava diretamente com o Decreto-Lei n²5/1937. Segundo essa perspectiva, o decreto não se proporia a proteger "toda uma categoria de bens, mas tão somente àqueles que lhes possa atribuir um valor individualizado, através de critérios a serem definidos - quer seja de excepcionalidade, memorabilidade, singularidade, exemplaridade etc" 12 . Além disso, o disposto em seu art. 17 - "As coisas tombadas não poderão, em caso nenhum ser destruídas, demolidas ou mutiladas" - iria de encontro às ações previstas nas pesquisas arqueológicas ${ }^{93}$. 
A bibliografia que discute a promulgação da Lei n 3924/ 1961 ainda dá especial destaque às iniciativas de centros de pesquisa de universidades brasileiras, a promulgação de legislações estaduais específicas (notadamente no Paraná e em São Paulol e o papel das missões científicas estrangeiras ${ }^{94}$, além do impulso dado ao tema pela Recomendação de Nova Delhi, de 1956. Tais iniciativas envolveram instituições e agentes atuantes no campo das pesquisas arqueológicas, como Loureiro Fernandes e o Centro de Estudos e Pesquisas Arqueológicas (CEPA/ UFPR), Luiz de Castro Faria, Heloísa Alberto Torres e o Museu Nacional/UFRJ ${ }^{95}$, Paulo Duarte e a Comissão de Pré-História ${ }^{96}$, os quais, de diversas formas, estiveram em contato ou acionaram a DPHAN para participar mais ativamente do debate. A arqueóloga Regina Coeli Pinheiro da Silva discute inclusive os diversos contatos que Paulo Duarte teria estabelecido com Rodrigo Melo Franco de Andrade, com vistas a "um trabalho de conscientização, no âmbito do governo federal, objetivando a preservação de todos os sítios pré-históricos, em especial os sambaquis e as grutas, principais alvos de exploração econômica"97. Mais tarde, com Renato Soeiro como diretor, já na vigência da Lei n 3924/ 1961, o tema da proteção das jazidas permanecia nas conversas promovidas por Duarte com a direção da DPHAN.

A literatura sobre o tema destaca, de fato, o envolvimento de Rodrigo Melo Franco de Andrade e da diretoria a que estava à frente no processo de elaboração da legislação, assim como remete à década de 1920 a "primeira proposta efetiva de preservação do patrimônio arqueológico brasileiro"98. Segundo Mario Pragmácio Telles, as propostas do conservador Alberto Childe teriam sido incorporadas ao Decreto-Lei n²5/1937

através dos seus artigos $1^{\circ}$ e $4^{\circ}$, conferindo guarida ao patrimônio arqueológico juntamente com os demais bens e criando um livro específico para a inscrição destes tipos de bens, o Livro do Tombo Arqueológico, Etnográfico e Paisagístico ${ }^{99}$.

A partir de 1940, o então Serviço do Patrimônio Histórico e Artístico Nacional teria dado início aos esparsos tombamentos de bens arqueológicos notadamente sítios e coleções, alcançando, segundo Regina Coeli Pinheiro da Silva, a cifra de apenas sete bens tombados até os 1960, aproximadamente 1\% dos bens tombados desde a fundação do serviço ${ }^{100}$. $\bigcirc$ número de artigos sobre bens e coleções arqueológicos publicados nas páginas da Revista do Patrimônio em seus 30 primeiros anos de existência também não impressiona pela quantidade, totalizando apenas quatro textos ${ }^{101}$. Esses números vão ao encontro do que se apontou acima sobre as preocupações sobre as limitações e a efetividade do Decreto-Lei n 25/1937 para a proteção dos bens arqueológicos. $\bigcirc$ próprio Rodrigo Melo Franco de Andrade afirmaria, em texto de 1952, que essa tarefa teria ficado delegada a outra instituição:

\footnotetext{
inventário e a proteção do material arqueológico do Brasil permaneceu a cargo do Museu Nacional, não tendo podido, por enquanto, a Diretoria do Patrimônio Histórico e Artístico assumir a responsabilidade de sucedê-lo nessa tarefa ${ }^{102}$.
}

94. Ver Tânia Andrade de Lima (1987); Regina Coeli Pinheiro da Silva (1996); Cristiana Barreto (1999, 2000).

95. Ver Lucieni de Menezes Simão (2000); Tânia Andrade de Lima (1987).

96. Ver Tânia Andrade de Lima (1987); Regina Coeli Pinheiro da Silva (1996).

97. Ver Regina Coeli Pinheiro da Silva (1996, p. 17-18).

98. Cf. Regina Coeli Pinheiro da Silva (1996, p. 11); Mario Ferreira de Pragmácio Telles (s/d); Rodrigo Melo Franco de Andrade (2012, p. 68-70).

99. Cf. Mario Ferreira de Pragmácio Telles (s/d).

100. Ver Regina Coeli Pinheiro da Silva (1996, p. 16).

101. Ver Heloisa Alberto Torres (1937, p. 9-30); Alberto Lamego (1940, p.55-82); Gastão Cruls (1942, p.169220); Maria da Conceição Beltrão e Roque de Barros Laraia (1969, p.203-218). Agradeço a Helena Santos pela indicação dos artigos.

102. Cf. Rodrigo Melo Franco de Andrade (2012, p. 160). 
103. Ver Regina Coeli Pinheiro da Silva (1996 p. 15 e 20).

104. Cf. Mario Ferreira de Pragmácio Telles (s/d).

105. Ver Regina Coeli Pinheiro da Silva (1987, p. 210-211).

106. Lei $\mathrm{n}^{\circ} 3924$, de 26 de julho de 1961.

107. Conforme se lê no portal do Centro de Estudos e Pesquisas Arqueológicas, da Universidade Federal do Paraná. Disponível em: $<$ http://www.humanas.ufpr. br/portal/cepa/outraspesquisas $>$, acesso em: 04 nov. 2015.

108. Disponível em: <http:// www.planalto.gov.br/ ccivil_03/decreto-lei/ Del0227.htm>, acesso em: 04 nov. 2015. Ver, sobre isso, Regina Coeli Pinheiro da Silva (1996).

109. Disponíveis, respectivamente, em: $<\mathrm{http}: / /$ www2.camara.leg. b r / 1 e g i n / f e d / decret/1960-1969/decreto62203-31-janeiro-1968403321-publicacaooriginal-1pe.html $>$ e $<$ http://www2. camara.leg.br/legin/fed/ decret/1960-1969/decreto65057-26-agosto-1969406746-publicacaooriginal-1pe.html>, acesso em: 04 nov. 2015.
Se, por um lado, essa colaboração do Museu Nacional propiciara formas de conhecer e de proteger mais amplas do que o tombamento, por outro, segundo Regina Coeli Pinheiro da Silva, teria resultado "numa ilusória desnecessidade de organização e de estruturação da área específica", estruturação essa que só aconteceria na década de $1980^{103}$. Essa interpretação parece ir ao encontro do que se notou em termos de iniciativas para a preservação dos sítios arqueológicos na década de 1960: participação da DPHAN, mas protagonismo de outros agentes.

A comissão selecionada para elaborar um projeto de lei com vistas à proteção específica dos bens arqueológicos, da qual Franco de Andrade fazia parte, vinculou tal proteção "a uma prévia autorização do já existente Departamento do Patrimônio Histórico e Artístico Nacional - DPHAN" 104 , conforme se lê no artigo 27 da Lei $n^{\circ} 3924$. Por outro lado, após a promulgação da Lei e pelos próximos vinte anos, a instrução de tombamentos dessa tipologia de bens, segundo Silva, teria sofrido um "congelamento"105: nesse período, teria havido apenas um bem arqueológico tombado em 1962, a Lapa da Cerca Grande, em Matosinhos, Minas Gerais.

No entanto, é possível identificar uma série de iniciativas nos anos 1960 que acionaram outras áreas e órgãos para além, ou mesmo independentemente, da DPHAN, as quais indicam esses outros espaços em que a preservação dos bens arqueológicos, considerados, desde 1961 , "para todos os efeitos bens patrimoniais da União"106, foi colocada. É o caso da criação do Programa Nacional de Pesquisas Arqueológicas, em 1965, financiado pelo Smithsonian Institution, de Washington D.C., e pelo Conselho Nacional do Desenvolvimento Científico e Tecnológico (CNPq); assim como do Programa Nacional de Salvamento, no mesmo ano, financiado, por sua vez, pela DPHAN e Centro de Ensino e Pesquisas Arqueológicas (CEPA/UFPR)107. Também é exemplo disso a articulação da Comissão de Pré-História com o governo federal, por meio do Ministério da Agricultura e seu Departamento de Produção Mineral, para excluir os sítios arqueológicos da área de abrangência do Ministério de Minas e Energia como jazidas para exploração econômica, por meio do Decreto-Lei n 227/1967, Art. 10, inciso $\|^{108}$. Ou mesmo, no que diz respeito a fiscalização e concessão de licenças para expedições científicas no Brasil, a promulgação dos Decretos $n^{\circ}$ 62.203, de 31 de janeiro de 1968, e n 65.057, de 26 de agosto de 1969109.

Um tratamento mais específico do Iphan em relação ao patrimônio arqueológico viria a ser notado nos anos 1980, com a criação de um Núcleo de Arqueologia, incorporado pouco depois à estrutura como Coordenadoria de Arqueologia da então Secretaria do Patrimônio Histórico e Artístico Nacional. É importante ressaltar, nesse mesmo contexto, a promulgação da Lei n 6938/1981, que dispunha sobre a Política Nacional do Meio Ambiente. Nela, pode-se destacar, novamente, preocupação com a relação entre desenvolvimento e preservação mais especificamente voltada para o meio ambiente - como se lê em seu artigo 4\%: "A Política Nacional do Meio Ambiente visará à compatibilização do 
desenvolvimento econômico-social com a preservação da qualidade do meio ambiente e do equilíbrio ecológico" 110. Para tanto, propunha uma série de medidas, entre as quais a criação de instrumentos para analisar impactos "considerados efetiva ou potencialmente poluidores, bem como os capazes, sob qualquer forma, de causar degradação ambienta|"111, como a avaliação de impacto ambiental e o licenciamento ambiental, largamente utilizados até os dias de hoje. Seriam esses instrumentos que motivariam, no final de década de 1990 e início dos anos 2000, um grande boom das pesquisas arqueológicas fiscalizadas pelo Iphan, o que seria reforçado, em seguida, pela criação do Programa de Aceleração do Crescimento e seu investimento maciço em grandes obras de infraestrutura. Novamente, e em continuidade desde os anos 1950-1960, a preservação era instada a encontrar formas de resistir ou se harmonizar ao desenvolvimento, o que impactava também o tratamento delegado aos "monumentos naturais, bem como os sítios e paisagens que importe conservar e proteger" 112 .

Ainda que tais monumentos naturais, sítios e paisagens fossem, desde 1937, alvo de proteção do Estado, com menção na Constituição outorgada naquele ano ${ }^{113}$ e no artigo $1^{\circ}, \S 2^{\circ}$ do Decreto-Lei $n^{\circ} 25$, no qual foram equiparados aos "bens móveis e imóveis existentes no país e cuja conservação seja de interesse público"114, a proteção de bens naturais pelo órgão federal de preservação, no Brasil, foi sempre muito modesta. Não configurou como prioridade em nenhum momento da história da instituição, mas questões relativas ao cancelamento do tombamento de um bem para viabilizar a exploração econômica e debates na década de 1960 sobre a necessidade de uma ação mais extensiva da DPHAN colocam o tema como fundamental para esta discussão.

Simone Scifoni, em A construção do patrimônio natural, aborda a pouca representatividade dessa tipologia de bens no acervo patrimonial constituído ao longo dos anos e fala mesmo em uma "recusa da incorporação do tombamento das áreas naturais nas práticas patrimoniais". Nesse sentido, mostra números contundentes, quando compara os 21 mil edifícios tombados e 79 centros urbanos igualmente protegidos aos " 39 bens que poderiam ser enquadrados na categoria de patrimônios naturais"115. Mônica Castro de Oliveira também destaca números relativos à proteção federal de bens naturais ${ }^{116}$, recuperando a relação de bens tombados entre 1938 e 1946 pelo então SPHAN, apresentada por Marcia Chuva, com oito bens distribuídos nas categorias "paisagístico", "arqueológico", "paisagístico científico" e até "cidade"117. Silvana Rubino, por sua vez, ao apresentar os tipos de bens tombados pelo Iphan até 1967, trabalha com "parques/ áreas naturais" e indica que haviam sido inscritos apenas cinco bens nessa categoria, ou 0,7\% do total de bens tombados até então ${ }^{118}$. Já Scifoni teria identificado 16 bens naturais tombados entre 1938 e 1967119.

Ainda na análise dessa autora, é possível perceber ao longo da trajetória do Iphan ênfases distintas ao tombamento de bens naturais. Entre os primeiros tombamentos do então SPHAN, os bens naturais tombados teriam sido reconhecidos, segundo Scifoni, devido à "valorização de paisagens expressivas, muitas dessas,
110. Lei $\mathrm{n}^{\circ} 6938$, de 31 de agosto de 1981 , artigo. $4^{\circ}$, alínea I, grifos meus. CF. Brasil (1981).

111. Idem, artigo 10.

112. Decreto-Lei ${ }^{\circ} 25$, de 30 de novembro de 1937, art. $1^{\circ}, \S 2^{\circ}$. Cf. Brasil (1937a).

113. Constituição dos Estados Unidos do Brasil, 10 de novembro de 1937 . Ver Brasil (1937b)

114. Decreto-lei n ${ }^{\circ} 25$, de 30 de novembro de 1937, art. $1^{\circ}, \S 2^{\circ}$. Cf. Brasil (1937a).

115. Cf. Simone Scifoni (2006, p. 91). A lista elaborada por Scifoni, presente na página 95 de sua tese, abarcou tombamentos entre $1938 \mathrm{e}$ 2005. A lista atualmente disponível dos bens tombados pelo Iphan até 2015 apresenta as categorias "patrimônio natural" e "jardins históricos", as quais - entre outras, como "conjunto urbano", "conjunto arquitetônico", "edifício e acervo", "sítio arqueológico", nas tipologias propostas no presente - englobam os bens indicados por Scifoni. Ver Lista de Bens Tombados e Processos em Andamento (1938 - 2016), disponível em: <http://portal.iphan. gov.br/uploads/ckfinder/ arquivos/Lista_Bens_ To m b a d o s Iphan_2015.pdf>, acesso em: 05 dez. 2015.

116. Ver Mônica Castro de Oliveira (2015, p. 35).

117. Ver Marcia Chuva (2009).

118. Ver Silvana Rubino (1996, p. 97-105).

119. Ver Simone Scifoni (2006, p. 95). Para Scifoni, a imprecisão terminológica usada para se referir a bens que podem ser tomados como bens ou patrimônio naturais teve impacto nessa 
variedade de números, resultando na dificuldade de estabelecer com precisão como o atual Iphan lidou com esse tipo de bens ao longo de sua trajetória. Nesse sentido, a autora recorreu a uma p r o b l e m a t i z a çã o terminológica para identificar o "patrimônio natural", propondo as categorias de "Serras, morros, montes e picos", "Grutas", "Parques Nacionais", "Parques e áreas verdes urbanas" e "Outros", a partir das quais teria identificado os que se aproximariam, segundo ela, da definição de patrimônio natural.

120. Ibid. (p. 98).

121. Cf. Carlos Fernando Moura Delphim (2009, p. 76).

122. Cf. Maria Cecília Londres Fonseca (1996, p.159).

123. Ver Simone Scifoni (2006, p. 93).

124. Cf. Ata da reunião do Conselho do Patrimônio Histórico e Artístico Nacional, de 13 de junho de 1961, disponível em: <http://portal.iphan.gov.br/

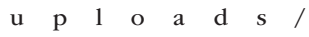
atas/1961__03_-35a reunio_ordinria__13_de_ junho.pdf $>$, acesso em 16 ago. 2015.

125. Parecer do Consultor Geral de República, Adroaldo Mesquisa da Costa, em 04 de maio de 1965. Ver Adroaldo Mesquita da Costa (1965).

126. Ver Ata da reunião do Conselho do Patrimônio Histórico e Artístico Nacional, de 25 de junho de 1962, disponível em: <http://portal.iphan.gov.br/ u $\quad \mathrm{p} \quad \begin{array}{llllll} & \mathrm{o} & \mathrm{a} & \mathrm{d} & \mathrm{s} & /\end{array}$ atas/1962_02_39a reunio_ordinria_25_de_ junho.pdf>, acesso em: 16 ago. 2015. cenários envolventes de edificação de interesse histórico" 120. Carlos Fernando Delphim, por sua vez, fala do tombamento de bens naturais pelo SPHAN, "imediatamente após sua criação", a partir, principalmente, de "aspectos paisagísticos ou históricos", mesmo que o autor estivesse, em sua argumentação, procurando demonstrar o interesse da instituição por "bens de valor geológico, geomorfológico, espeleológico e outros"121. Para Maria Cecília Londres Fonseca, de forma geral, tratava-se de "bens naturais apreciados, fundamentalmente, de um ponto de vista estético" 122.

Nos anos 1960, porém, identificaram-se debates específicos sobre os bens naturais e sua preservação no âmbito do patrimônio. É possível imaginar que, em certa medida, isso tenha sido motivado pelo cancelamento do tombamento do Pico de Itabira ou Pico de Itabirito e Conjunto Paisagístico ${ }^{123}$, que fora inscrito no Livro Arqueológico, Etnográfico e Paisagístico. Segundo deliberação do Conselho Consultivo do Patrimônio Histórico e Artístico Nacional, em 1961, esse tombamento devia-se tanto à "singularidade do Pico de Itabirito entre os monumentos naturais do país, bem como à sua excepcional beleza paisagística" como à intenção, daquele conselho, de fazer prevalecer "o interesse público no sentido de preservarthe a integridade (...) sobre os interesses privados dos proprietários e dos concessionários da lavra, cujos proventos obtidos no local compensam, aliás, amplamente a proteção devida ao monumento"124. Imediatamente após a notificação do tombamento, os proprietários - St. John D'El Rey Mining Company Limited, Companhia de Mineração Novalimense e Icominas S. A - Empresa de Mineração ${ }^{125}$ - apresentaram impugnações que foram porém indeferidas, e, em junho de 1962, o conselho decidiu por seu tombamento definitivo ${ }^{126}$.

No entanto, as empresas mineradoras mantiveram-se firmes no intento de revertê-lo e, em 1965, como resposta às suas insistências, foi emitido parecer da Consultoria Geral de República, que destacou principalmente os "prejuízos de monta" que as empresas teriam, não apenas por não poderem exercer as atividades de lavra pretendidas, mas também porque o tombamento fora determinado sem nenhuma indenização aos proprietários ${ }^{127}$. Esse parecer embasou o despacho do presidente da República Castelo Branco que, em junho de 1965, já sob o regime militar e coerentemente com as políticas desenvolvimentistas encampadas então, destacou a importância da exportação do minério de ferro para o governo e as condições precárias das finanças que não permitiriam uma devida indenização aos proprietários, conforme sugerido no parecer do consultor geral. Determinou, portanto, o cancelamento do tombamento do Pico do Itabirito ${ }^{128}$, afirmando que a exploração do minério a ser ali desenvolvida seria "um fato econômico de efeito certo e conhecido", ao passo que descreveu o tombamento como "um ato administrativo de resultados controversos, embora valiosos" ${ }^{\prime \prime 2}$.

Nota-se como a exploração econômica do patrimônio tombado se colocou, nesse episódio, como rival de monta para a DPHAN frente a projetos e interesses de viés desenvolvimentista, motivando inquietação quanto ao futuro de bens arqueológicos, como visto acima, e dos bens naturais. De maneira geral, os anos 1960 foram bastante marcados, nacional e internacionalmente, por 
preocupações com a preservação da natureza: deu-se, em 1962, a primeira Conferência Mundial de Parques Nacionais, em Seattle, promovida pela União Internacional para a Conservação da Natureza (UICN), contando "pela primeira vez na história do movimento ambientalista internacional" com países da África e da América Latina ${ }^{130}$; foi promulgado o Novo Código Florestal brasileiro, com a Lei n 4.771/1965, revendo o texto do primeiro Código Florestal, de 1934; houve também a ratificação, no Brasil, da Convenção para a Proteção da Flora, Fauna e das Belezas Cênicas dos Países da América, de 1940, elaborada no contexto da União Panamericana, com especial destaque aos Parques e Reservas Nacionais, por meio do Decreto n 58.054/1966131; ocorreu a Conferência da Biosfera, realizada pela Unesco em 1968, em Paris; entre outros ${ }^{132}$. Essas iniciativas devem ser entendidas como respostas articuladas de um movimento ambientalista cada vez mais organizado e com demandas por uma ação mais efetiva do Estado na preservação do patrimônio natural frente aos programas desenvolvimentistas ${ }^{133}$

É significativo que a conservação da natureza, por meio da atenção a bens naturais, fosse ganhando progressivamente mais espaço também no âmbito da instituição federal de patrimônio no Brasil. Vale destacar, nos seus primeiros anos de funcionamento, algumas iniciativas da DPHAN que indicam sua preocupação com o tema da natureza no âmbito do patrimônio: tem-se os tombamentos de bens naturais, a produção de conhecimento e a discussões sobre o tema, como na publicação do artigo "A natureza e os monumentos culturais", de Raimundo Lopes, do Museu Nacional, no primeiro número da Revista do Serviço do Patrimônio Histórico e Artístico Nacional, em 1937134, além das inúmeras menções ao assunto na documentação arquivada no ACl/RJ, em trocas de correspondência entre técnicos da Diretoria do Patrimônio e entre eles, outras instâncias do governo e organismos internacionais ${ }^{135}$; merece destaque ainda que a DPHAN se envolvesse em iniciativas de debates públicos sobre o tema, como demonstra sua participação na II Mesa Redonda de Informação sobre Conservação da Natureza, ocorrida no Rio de Janeiro, entre 30 de novembro a 7 de dezembro de 1967. Nessa ocasião, Luís Saia, arquiteto cuja trajetória por vezes se confunde com a atuação do Iphan em São Paulo, apresentou a comunicação "O papel da Diretoria do Patrimônio Histórico e Artístico Nacional na proteção de sítios e paisagens"136.

Nessa comunicação, cujo original anotado se encontra no $\mathrm{ACl} / \mathrm{RJ}$, encontram-se tratados vários aspectos que compõem a discussão aqui proposta, com destaque para as preocupações quanto à aceleração do potencial transformador das tecnologias desde a década de 1950, relacionadas em larga medida a atividades econômicas. Tal aceleração era entendida, por um lado, como "contribuição positiva favorável naquilo que diz respeito ao progresso material e à cultura", mas também, por outro, como causadora de "desfalque" e "perdas irremediáveis" ao "patrimônio do Brasil". Saia fez também referência explícita ao cancelamento do tombamento do Pico do Itabirito, ocorrido dois anos antes, apresentando-o como exemplo negativo a ser prevenido. Procurou, nesse mesmo sentido, indicar as ações realizadas pela DPHAN do que diz respeito à
127. Ver Adroaldo Mesquita da Costa (1965).

128. O cancelamento do tombamento de bens do patrimônio histórico e artístico nacional estava previsto desde 1941, com a publicação do Decreto-Lei $\mathrm{n}^{\circ} 3866 / 1941$, o qual estabelecia que o Presidente da República poderia determinar que, "atendendo a motivos de interesse público, (...) seja cancelado o tombamento de bens pertencentes à União, aos Estados aos Municípios ou a pessoas naturais ou jurídicas de direito provado, no Serviço do Patrimônio Histórico e Artístico Nacional, de acordo com o Decreto-Lei $\mathrm{n}^{\circ} 25$, de 30 de novembro de 1937." Ver Brasil (1941).

129. Cf. Adroaldo Mesquita da Costa (1965, p. 341).

130. Ver João Vitor Campos de Souza (2013, p. 42).

131. Disponível em: <http:// www2.camara.leg.br/legin/ fed/decret/1960-1969/ decreto-58054-23-marco-1966-398707-publicacaooriginal-1-pe.html>, acesso em: 05 dez. 2015.

132. Agradeço a Luciano de Souza e Silva pelas informações e referências a respeito do movimento ambientalista e iniciativas em prol da preservação da natureza ao longo do século XX.

133. Vale ressaltar que tal preocupação era mais antiga: internacionalmente, tem-se, por exemplo, a criação da União Internacional para a Preservação da Natureza (atual UICN), em 1948; no Brasil, são dignos de nota, entre outros, a promulgação do primeiro Código Florestal brasileiro, por meio do Decreto $\mathrm{n}^{\circ} 23.793$, de 23 de janeiro de 1934; as menções à proteção de monumentos naturais na Constituição de 
1937 e no Decreto-Lei $\mathrm{n}^{\circ}$ 25/1937; e a criação da Fundação Brasileira para a Conservação da Natureza, em 1958, com sede no Rio de Janeiro. Cf. José Luiz de Andrade Franco, (2009, p. 59-84).

134. Ver Raimundo Lopes (1937, p. 77-96). Vale destacar a ênfase do autor na relação entre cultura e natureza e na vinculação entre conservação da natureza e a valorização de "monumentos, cidades históricas e jazidas arqueológicas”.

135. As séries "Arquivo Técnico Administrativo" e "Assuntos Internacionais" do ACI/RJ são especialmente interessantes para pesquisas nesse sentido. No que diz respeito aos contatos da DPHAN com a Unesco, por exemplo, nos documentos da série "Assuntos Internacionais", são constantes as menções às preocupações dessa organização com a "proteção da natureza" e a "recuperação dos recursos naturais".

136. Cf. Luís Saia (1967). Teve-se acesso a cópia impressa da comunicação oral preparada por Saia para o evento.

137. Decreto-Lei $n^{\circ} 25$, de 30 de novembro de 1937 , art, $1^{\circ}, \S 2^{\circ}$, grifos meus. Cf. Brasil (1937b).

138. Cf. Luís Saia (1967).

139. Ibidem.

140. Ibidem. É possível entender essa afirmação discutindo diretamente com o evento do cancelamento do tombamento do Pico do Itabirito, na medida em que Saia menciona o fato de o tombamento não prever desapropriação.

141. Cf. Luís Saia (1967). proteção de sítios e paisagens (mesma terminologia usada na Recomendação de Paris, de 1962), com vistas à apresentação de uma "uma hipótese de trabalho".

O que Saia propôs como principal contribuição de sua comunicação foi a sistematização de "um rol de critérios (...) para focalizar melhor os diferentes aspectos do problema, fundando a sua análise em dados objetivos e concretos" com vistas ao tombamento de bens naturais. Juntamente com os "critério de testemunho" e "critério estético", mais diretamente relacionados a noções e conceitos com que a DPHAN vinha trabalhando desde os anos 1930, o técnico da DPHAN indicou um "critério de valor científico pedagógico", que resultaria da articulação de áreas de conhecimento diversas, e ainda os "critério de proposição econômica" e "critério de vinculação humana (pré-história e história)". Nestes dois últimos, a abordagem aproxima-se das preocupações deste artigo: no que tange à vinculação humana às áreas naturais de interesse, Saia reforça o recorte estabelecido no Decreto-Lei n ${ }^{\circ}$ 25/1937, valorizando a "feição notável com que [os monumentos naturais, sítio e paisagens] tenham sido (...) agenciados pela indústria humana" 137 e destacando, portanto, os monumentos naturais com vestígios de ocupações, feitos ou simbologias humanos. Tal "indústria humana" poderia significar desde inscrições rupestres, como na Serra da Borborema e também em Campina Grande, na Paraíba, até a "criação de um novo tipo de paisagem", com as vastas áreas alagadas por obras de infraestrutura, como as represas de Três Marias, inaugurada em 1962, e de Furnas, de 1963'38.

Nessa perspectiva, os empreendimentos estariam sendo valorizados como "uma iniciativa do homem capaz de representar um novo quadro de vivência", tão legítima como outras do passado para o campo do patrimônio ${ }^{139}$. Nota-se aí a linha argumentativa de Saia sobre a "contribuição positiva favorável" dos avanços tecnológicos e do desenvolvimento. Já as "perdas irremediáveis", que o arquiteto também sublinhou, apareceriam, como descrito no "critério de proposição econômica", na necessidade de o tombamento "anteceder de todo à ocupação econômica", ou, em outros termos, num claro reconhecimento da dificuldade de a preservação conseguir competir com os interesses e avanços das políticas desenvolvimentistas de então, na constatação de que as ações de preservação seriam facilitadas "na medida em que a ocupação econômica da região onde se insere a área tombável estiver ainda em nível incipiente." 140 Para tanto, seria importante uma ação contundente em relação aos bens naturais:

No tocante à proteção dos monumentos naturais a DPHAN se encontra, pois, no momento, face à necessidade de uma ação extensiva do mesmo tipo daquela que enfrentou durante seus primeiros 30 anos de vida em relação aos monumentos arquitetônicos ${ }^{141}$.

Ainda que tal ação extensiva não tenha sido notada, pelo menos não nos mesmos moldes dos tombamentos de bens arquitetônicos ainda no final da década de 1930, percebe-se, efetivamente, que o tema do patrimônio natural e de sua proteção ganhou, nesse momento, mais espaço no âmbito do patrimônio, em geral, e na DPHAN, em particular: 
Gráfico 1 - Patrimônio natural tombado pelo Iphan até 2015

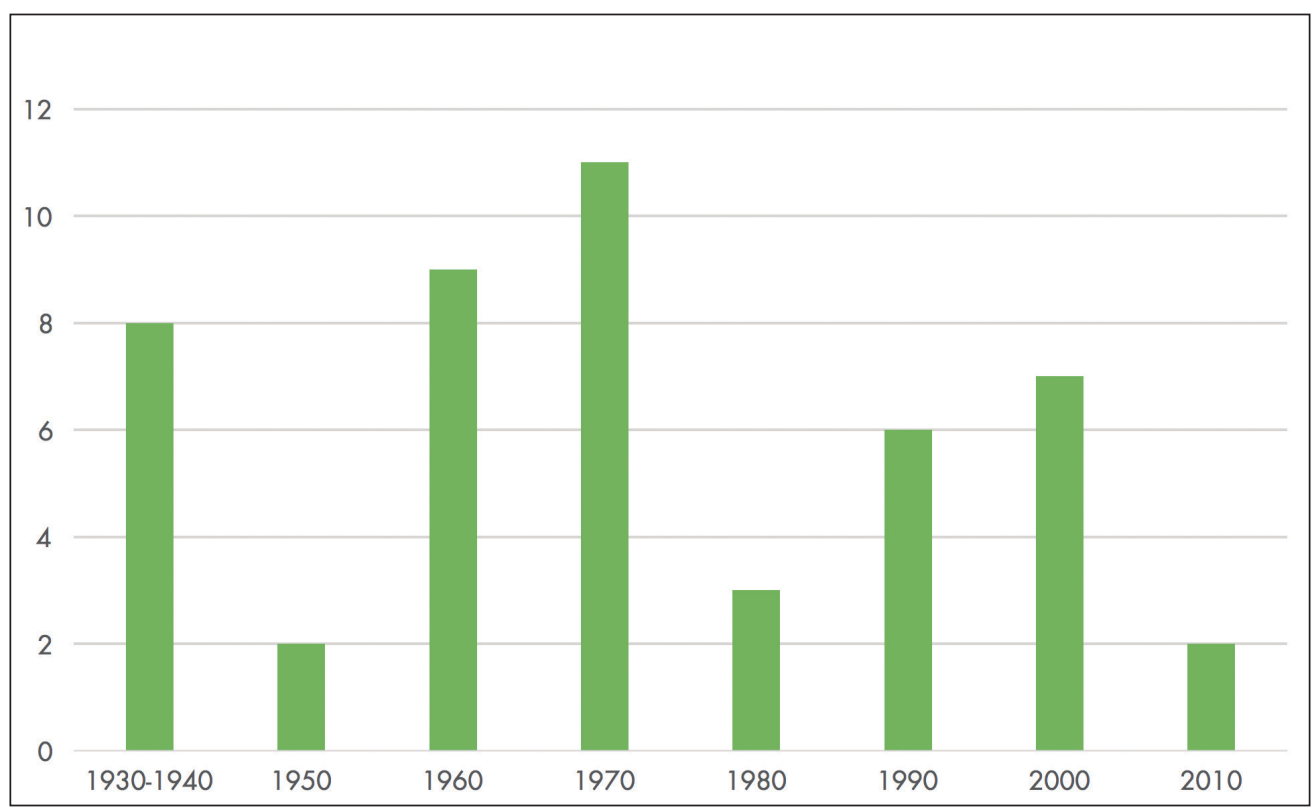

Fonte: Lista de Bens Tombados e Processos em Andamento (1938-2016), Iphan; Simone Scifoni (2006, p. 95).

Segundo o Gráfico 1, nota-se que os números alcançados nos primeiros anos de atuação do Serviço do Patrimônio só teriam equivalência nas décadas de 1960 e 1970, sendo então superados com o tombamento de nove e onze bens, respectivamente, nas categorias (usadas atualmente) "patrimônio natural" e "jardins históricos" e naquelas indicadas por Scifoni em sua tese, em 2006 ${ }^{142}$. Trata-se, justamente, do momento em que os perigos a esses bens, por meio dos avanços dos interesses econômicos, alcançaram maior evidência até o momento. É possível perceber, nesses dois decênios, um aumento importante na preocupação com o patrimônio natural, ou, nos termos de Scifoni, "o auge" do reconhecimento a esses bens, o que representou, em termos de tombamentos, mais de 40\% das inscrições até $2015^{143}$. A preocupação com a iminência de "perdas irremediáveis" parece ter influenciado fortemente esse investimento da DPHAN nas discussões e ações de proteção em relação aos bens naturais, assim como, simultaneamente, a parte do patrimônio edificado localizada, principalmente, em áreas urbanas, sujeita, naquele momento, ao crescimento desordenado das cidades. No que diz respeito ao patrimônio edificado no Brasil, convencionou-se afirmar que, a partir de meados dos anos 1960, "do ponto de vista de orientação de trabalho, inicia-se uma nova política de tombamentos, dirigida mais para a preservação de conjuntos" ${ }^{144}$. Essa perspectiva refletia debates internacionais, notadamente europeus, sobre formas de repensar centros históricos para além de entendimentos estéticos, em suas dimensões urbana e documental e em termos articulados com os planos econômico e social ${ }^{145}$. Mas deu-se, principalmente, por causa da crescente industrialização, do crescimento
142. Ver Simone Scifoni (2006, p. 95).

143. Ibidem.

144. Cf. Brasil (1980a, p. 20).

145. Ver Marcia Sant'Anna (2015, p. 72,80$)$. 
146. Ibid. (p. 202).

147. Ibid. (p. 129).

148. Ibid. (p. 169).

149. Ver Silvana Rubino (1996, p. 98).

150. Ibidem; Marcia Sant'Anna (2015, p. 169).

151. Para dar apenas dois exemplos disso, tem-se o já citado Pico de Itabira Conjunto Paisagístico e Pico do Itabirito - que é a denominação do bem -, inserido na categoria atual de "paisagem"; e a Igreja de Santo Alexandre e antigo Colégio dos Jesuítas, definidos como "conjunto arquitetônico", conforme se lê em Iphan. Ver Lista de bens tombados e processos em andamento (1938-2015), do Iphan, disponível em: <http://portal.iphan.gov.br/ uploads/ckfinder/arquivos/ Lista_Bens_Tombados_pelo_ Iphan_2015.pdf>, acesso em: 05 dez. 2015.

152. É o caso, por exemplo, das Rua Carneiro de Campos, Sodré e Travessa Aquino Gaspar - conjunto arquitetônico tombado em 1964, em Salvador, e inscrito no Livro do Tombo Arqueológico, Etnográfico e Paisagístico. Cf. Lista de bens tombados e processos em andamento (1938-2015), do Iphan, disponível em: <http://portal.iphan.gov.br/ uploads/ckfinder/arquivos/ Lista_Bens_Tombados_pelo_ Iphan_2015.pdf>, acesso em: 05 dez 2015.

153. Como é o caso do conjunto urbano denominado "Acervo Arquitetônico e Urbanístico Art Déco de Goiânia”, tombado em 2005 nos Livros do Tombo Arqueológico, Etnográfico e Paisagístico, Histórico e de Belas Artes; ou o conjunto rural Engenho Matoim, tombado em Candeias, na Bahia, em 1943, e que inclui o sobrado e fábrica de açúcar. Cf. Lista de bens tombados e processos das cidades, da especulação imobiliária que se notabilizaram a partir dos anos 1950 e se agudizaram nos anos 1960, transformando a preservação urbana em um "problema especial no final da gestão de Rodrigo M. F. de Andrade" 146.

Mesmo com discussões jurídicas já na década de 1940 sobre a preservação de áreas urbanas, como indica Márcia Sant'Anna ${ }^{147}$, a literatura tende a indicar a notável preferência, nas primeiras décadas de ałuação do Serviço do Patrimônio, por imóveis tomados individualmente - para essa autora, majoritariamente "exemplares da arquitetura religiosa e civil do período colonial"148; segundo Silvana Rubino, o imóvel religioso católico, seguido do urbano. Os números relativos aos tombamentos desse período, apresentados em artigo $\bigcirc$ mapa do Brasil passado, dessa autora, mostram a prevalência dos bens individuais edificados entre os tombamentos realizados durante a gestão de Rodrigo Melo Franco de Andrade, que totalizariam 231 exemplares, aproximadamente 1/3 do total de tombamentos entre 1938 e 1967, entre bens de arquitetura urbana, rural, religiosa, militar ou ligada ao Estado. Os conjuntos tombados, por sua vez, atingiriam apenas 26 nesse período, ou 3,8\% do total ${ }^{149}$.

Interessa nessa comparação tanto a constituição de uma tipologia ou categoria de bens - os conjuntos - a partir de um certo período da trajetória da DPHAN, como uma compreensão diferente dos efeitos e possibilidades das formas de proteção disponíveis.

Os números indicados acima sobre os bens tombados durante a gestão Rodrigo Melo Franco de Andrade e as análises de Marcia Sant'Anna e Silvana Rubino sobre eles dão um panorama geral sobre as tipologias privilegiadas ${ }^{150}$. É preciso, portanto, discutir a própria tipologia de "conjuntos" com que o órgão federal de preservação tem trabalhado. As ações de preservação dos bens culturais não foram sempre acompanhadas por um processo sistemático e organizado de conceituação desses bens, como já se viu acima sobre o patrimônio natural. Aparentemente, sua materialidade, por meio dos bens que eram seus referentes, e também as definições de campos disciplinares específicos e institucionalmente hegemônicos - notadamente da Arquitetura, das Belas Artes e também da História - bastavam para definir muitas das categorias privilegiadas, como igrejas, mosteiros e capelas; casas de câmara e cadeia, palácios, prefeituras; casas e sobrados; fontes, chafarizes, calçamentos. Trabalhar com a ideia de conjuntos no campo do patrimônio e, mais especificamente, analisar como foram tratados ao longo da trajetória do Iphan implica, necessariamente, trabalhar com diversas noções ao longo do tempo. Deve-se levar em conta, por exemplo, que se utiliza"conjunto", ora como denominação do bem, ora como categoria em que o bem está inserido ${ }^{151}$; ora na compreensão dos bens em sua contiguidade ${ }^{152}$, ora como exemplares que se relacionam em termos estilísticos, funcionais ou históricos ${ }^{153}$.

Ainda que haja uma categoria utilizada no presente pelo Iphan "Conjuntos Urbanos Tombados" (ou "Cidades Históricas") 154 -, para os fins deste artigo, vai se trabalhar com os "Processos de tombamento de áreas urbanas abertos pelo Iphan" no período de 1930-1990 identificados por Marcia Sant'Anna em 
apêndice de seu livro ${ }^{155}$, por se tratar de um estudo que investiu na problematização da noção de conjunto para o patrimônio. Para a autora, "os tipos básicos de conjuntos urbanos ou paisagísticos" protegidos pelo órgão em sua trajetória já estariam definidos nos primeiros tombamentos: tratava-se, grosso modo, de "fragmento composto por um monumento principal (em geral uma igreja) e seu ambiente próximo (em geral uma praça)", designado "Sob diversos nomes praça, outeiro, conjunto arquitetônico ou vila".

Gráfico 2 - Áreas urbanas tombadas pelo Iphan (1930-1990)

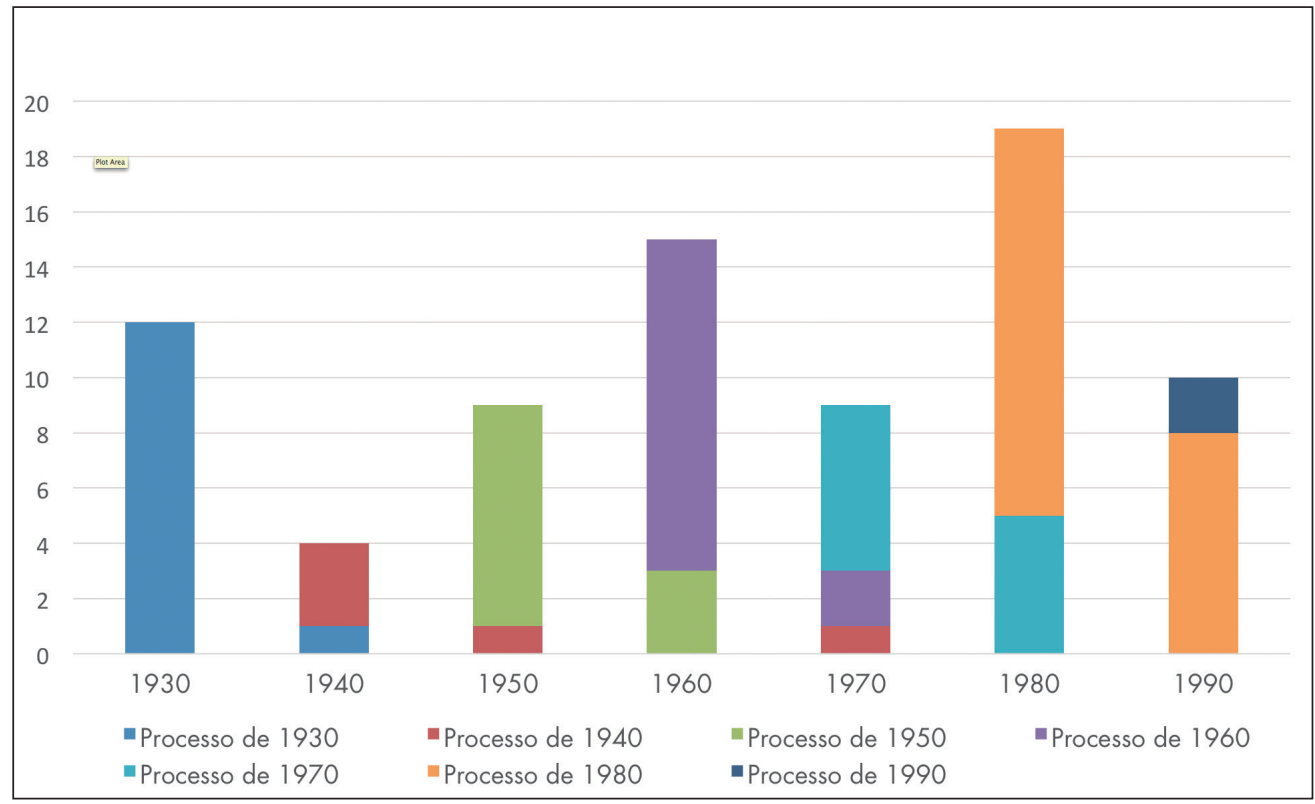

Fonte: "Processos de tombamento de áreas urbanas abertos pelo IPHAN (1938-1990)"156.

Observando o gráfico acima, além do alto investimento inicial no tombamento das "cidades-monumento" nos dois anos iniciais de atuação do Serviço de Patrimônio (1938 e 1939), nota-se o crescimento, a partir dos anos 1950 e 1960, do investimento institucional na proteção de áreas urbanas. A abertura dos processos de tombamento (indicados na legenda inferior e nas cores das colunas) e o tombamento efetivo de áreas urbanas (cujas datas estão indicadas no eixo " $x$ " do gráficol expandiram não só numericamente naquele período, mas também geograficamente, uma vez que os tombamentos eram limitados, principalmente, a Minas Gerais e Rio de Janeiro até então ${ }^{157}$, e conceitualmente - a importância de aspectos socioeconômicos e urbanos obrigou a uma leitura dos conjuntos que extrapolasse considerações apenas estéticas desses bens.

No que diz respeito aos procedimentos técnicos relacionados à proteção desses bens, notam-se importantes distinções: o tombamento de um bem tomado individualmente, por exemplo, sugeria tanto a preocupação com aquele exemplar específico como a confiança naquela ação como suficiente para sua proteção. em andamento (1938-2015), do Iphan, disponível em: $<$ http://portal.iphan.gov.br/ uploads/ckfinder/arquivos/ Lista_Bens_Tombados_pelo_ Iphan_2015.pdf>, acesso em: 05 dez 2015

154. Ver "Conjuntos Urbanos Tombados (Cidades Históricas)" disponível em: $<$ http://portal.iphan.gov.br/ pagina/detalhes/123>, acesso em: 05 dez 2015.

155. Cf. Marcia Sant'Anna (2015, pp. 387-398).

156. Cf. Apêndice H -"Processos de tombamento de áreas urbanas abertos pelo IPHAN (1938-1990)" in: Marcia Sant'Anna (2015, p. 387-398).

157. Ibid. (p. 173). 
158. Ver Rodrigo Melo Franco de Andrade (1987, p. $82)$.

159. Ibid. (p. 81).

160. Idem (p. 84).

161. Lia Motta e Analucia Thompson (2010, p. 38).
Interferências na vizinhança da coisa tombada eram proibidas, conforme se lê no artigo 18 do Decreto-lei $n^{\circ}$ 25/1937, a fim de não impedir ou reduzir sua visibilidade. Tombar um conjunto, porém, era diferente:

Importa salientar, como observação preliminar, que o objetivo da conservação da integridade de um sítio urbano não se confunde com a conservação dos monumentos individuais incluídos na respectiva área. Conquanto seja obviamente indispensável à preservação do sitio a proteção de cada uma das unidades arquitetônicas localizadas em seu perímetro, a manutenção e a defesa do conjunto urbano-paisagístico deverão constituir a meta predominante das autoridades públicas. Assim, se porventura algum monumento pudesse ser valorizado mediante a demolição de edificações secundárias em sua vizinhança, os agentes responsáveis pela conservação do sítio se recusariam a tomar semelhante iniciativa, atendendo à significação histórica do logradouro ou, noutra hipótese, considerando a desarmonia causada ao conjunto urbano pelo destaque excessivo e artificioso de determinada edificação ${ }^{158}$.

No artigo publicado pelo Jornal do Comércio postumamente à sua morte, em 1970, Rodrigo Melo Franco de Andrade indicara os critérios para a conservação dos conjuntos urbanos (título do artigo, por sinall). Ainda que lançasse mão da comparação com os procedimentos e diretrizes da preservação de edificações individuais, partia de uma noção mais ou menos clara de sítio urbano, entendido como "criação notável e representativa da vida e da organização social de um povo, em determinada fase de sua evolução", cuja preservação integral interessava pelo que representava "como produção valiosa e de espécie particular no acervo universal dos bens culturais" 159 . Nesse sentido, destacara ainda aspectos como a importância das áreas ou perímetros vizinhos aos monumentos, a relação entre eles e "edificações secundárias", a "significação histórica do logradouro" e a relevância da harmonia original entre as unidades que compunham o conjunto. Questões que, como se verá abaixo, já haviam sido propostas anos antes na Carta de Veneza, de 1964.

Ainda no mesmo artigo, Franco de Andrade teria afirmado que a deterioração de um sítio urbano, por exemplo, seria mais provável do que em edificações, estando relacionada tanto à perda dos fatores econômicos que o mantinham, como às "aspirações naturais de progresso" dos habitantes e decorrentes de "iniciativas públicas ou particulares", descritas como "incompatíveis com a preservação do aspecto peculiar das áreas e dos bens culturais a elas pertencentes" 160 . Nota-se, portanto, a importância dada a questões relativas ao desenvolvimento - fosse ele negativo ou positivo - e seu impacto sobre a sobrevivência de um sítio, assim como, conforme visto acima, os aspectos para os quais se deveria atentar na proteção específica dessa tipologia de bens, os conjuntos.

Lia Motta e Analucia Thompson destacam as décadas de 1960 a 1980 como um "período de fortalecimento e diversificação do uso do entorno como forma de preservação" e durante o qual o planejamento urbano teria se firmado na "proteção de bens imóveis e das áreas urbanas tombadas"161. Nesse sentido e na 
discussão identificada no artigo de Franco de Andrade, é importante recuperar a ênfase que a Carta de Veneza, de 1964 - descrita pelas autoras como "um marco para a preservação das áreas envoltórias dos monumentos" 162 - dava à noção de ambiência, assim como a importância dessa noção para a conservação e a compreensão dos monumentos não apenas como "obra de arte", mas também como "testemunho histórico", ou, conforme se lê no documento:

A noção de monumento histórico compreende a criação arquitetônica isolada, bem como o sítio urbano ou rural que dá testemunho de uma civilização particular, de uma evolução significativa ou de um acontecimento histórico. Estende-se não só às grandes criações, mas também às obras modestas, que tenham adquirido, com o tempo, uma significação cultural'b3.

Essa "ampliação da noção de monumento"164, que passa a ser entendido e proposto dentro de um recorte que incorpore edifícios contíguos sem, necessariamente, os mesmos atributos identificados nos imóveis valorizados individualmente, possibilitava ou implicava uma leitura desses bens como parte de um conjunto e a partir de uma perspectiva urbanística, o que ia ao encontro das pressões que o patrimônio protegido vinha sofrendo com o crescimento das cidades. Novamente segundo Motta e Thompson:

Tratava-se, em muitos casos, de um recurso para atender às novas demandas das comunidades urbanas pela preservação, que tinham como objetivo manter a qualidade de vidas nas cidades, diante das ameaças da especulação imobiliária ${ }^{165}$.

Percebem-se, nesse trecho, elementos destacados nesta discussão, principalmente no que foi apontado referentemente às Recomendações de Paris, de 1962 e 1968, e às Normas de Quito, de 1967, sobre a necessidade de compatibilização entre desenvolvimento econômico e o crescimento urbano, de um lado, e preservação dos bens culturais, de outro. Remetem também aos riscos apresentados pelas iniciativas que, segundo Rodrigo Melo Franco de Andrade, decorreriam das "aspirações naturais de progresso" dos habitantes de conjuntos urbanos, relacionando, portanto, preocupação com a qualidade de vida, bem-estar e direitos da população residente, tentativas de conter a especulação imobiliária e formas eficazes de preservação do patrimônio e, em especial, dos conjuntos urbanos.

A valorização desses conjuntos dava-se, portanto, a partir de um viés duplo: além dos procedimentos próprios da patrimonialização de bens culturais, que implica a atribuição de certos valores com vistas à justificativa de sua inscrição em um ou mais Livros do Tombo, deu-se sua valorização estratégica, social e econômica com vistas a compatibilizar desenvolvimento e preservação, fosse por meio de propostas de conservação integral de edificações e sítios, fosse pela discussão de conceitos como monumento, ambiência, entorno, vizinhança; pela relação entre edificações e a paisagem ou entre patrimônio e natureza; ou ainda pela incorporação ao fomento de seu potencial turístico, como largamente sugerido por peritos da Unesco que visitaram o Brasil e discutido neste artigo.
162. Ibid. (p. 19).

163. Trecho da Carta de Veneza, de1964. Cf. Isabelle Cury (2004, p. 92).

164. Cf. Lia Motta e Analucia Thompson (2010, p. 19).

165. Cf. Lia Motta e Analucia Thompson (2010, p. 38). 
Considerações finais

A intenção deste artigo foi destacar alguns aspectos referentes a discussões que se deram no âmbito do órgão federal de patrimônio durante os anos 1960 sobre suas ações, instrumentos, perspectivas e entendimentos, partindo da premissa de que teriam grande influência na conformação das políticas de patrimônio desse período e que podem ser lidas em suas especificidades contextual e histórica, em um processo que implica, necessariamente, continuidade e rupturas em relação aos períodos anteriores, e que contribui para os desenvolvimentos posteriores. Decorre dessa abordagem, crê-se, a importância da discussão para uma compreensão mais clara do momento histórico e para um debate sobre as políticas que se conformariam a partir de então, como o Programa Cidades Históricas, que é o tema da publicação em que este artigo está inserido.

O tema principal do artigo foi, nesse sentido, o aspecto que se entende como mais marcante desse período para as políticas de patrimônio: a relação entre patrimônio e desenvolvimento, no contexto marcado pelo investimento do Estado brasileiro, a partir já dos anos 1950, na industrialização, em novas tecnologias, no crescimento econômico, na urbanização. Contexto marcado também por discussões nacionais e internacionais sobre os sentidos e a efetividade da preservação do patrimônio frente aos impactos do desenvolvimento, em sua reação "contra as forças poderosas do mercado e da especulação imobiliária"160, e também contra a exploração econômica predatória de bens culturais, naturais, arqueológicos. Nesse sentido, organizou-se o texto em torno de duas perspectivas que ajudaram a problematizar as possibilidades da relação entre patrimônio e desenvolvimento, sempre atentas aos impactos deste sobre aquele: a primeira, partindo da confiança na articulação harmônica entre crescimento, exploração econômica e desenvolvimento, de um lado, e patrimônio e sua preservação, do outro. Destacaram-se, assim, os esforços internacionais e, em certa medida, coletivos, para elaborar diagnósticos e propor soluções a partir de políticas de cooperação e assistência intelectuais com foco principalmente no turismo. Essa atividade possibilitaria, segundo debates e entendimentos dos anos 1960, a articulação desejada entre a valorização do patrimônio cultural e natural, sua preservação, sua utilização econômica e o desenvolvimento das regiões onde estivessem localizados.

A segunda perspectiva estaria situada, de certo modo, nas falhas e insuficiências da primeira, naquilo em que a compatibilização entre desenvolvimento e preservação não pôde ou não poderia evitar ou propor. Estaria presente nas formas de resistir aos avanços do desenvolvimento e suas manifestações, partindo dos contextos e instrumentos disponíveis, de diagnósticos das situações e de possíveis perigos, e proporia maneiras de evitar ou mitigar os danos potenciais ou efetivos. Teria tido como um dos efeitos a proposição de temas de debate que eram ainda pouco recorrentes no campo do patrimônio, notadamente no Brasil, acarretando, de certo modo, na própria revisão da noção de patrimônio e do valor 
de patrimônio, com valorização de bens até então não consagrados pelos discursos patrimoniais, como os bens naturais, arqueológicos e os conjuntos tomados a partir de seus sentidos socioeconômicos e urbanos.

Nas duas perspectivas, buscou-se enfatizar, principalmente, os debates apropriados pela DPHAN, assim como aqueles que essa diretoria suscitou ou em que foi instada a se envolver, na crença da importância de posicionamento que tirou desses diálogos para a conformação de políticas de patrimônio a partir do período em questão. Salientou-se aqui a grande influência, mas não a influência exclusiva da DPHAN na conformação de tais políticas, assumindo um papel não necessariamente de protagonista, como se viu na elaboração da Lei de Arqueologia (Lei n ${ }^{\circ} 3924 / 1961$ ). Daí a importância de pensar os diálogos em que a DPHAN esteve envolvida, que tipos de influência sofreu por meio deles, como se colocou na construção de políticas e ações, e de que maneira reagiu diante de pressões, sugestões e interferências de outros campos de conhecimento, institucionalização e atuação. Em todos os aspectos tratados, buscou-se entender essa trama em que a DPHAN estava envolvida, fosse nos contatos com a Unesco e na participação do que se poderia pensar como a construção de um sistema internacional de patrimônio, que se organizava e pode-se dizer que se organiza ainda hoje a partir de organização internacional; fosse nos debates com universidades, instituições de pesquisa, ministérios variados; fosse ainda para além dos campos da cultura e do patrimônio, relacionando-se com os debates sobre mineração, natureza, ambiente, desenvolvimento, turismo, entre outros.

Vale, no contexto desta discussão, um esforço para perceber como ações aqui destacadas desdobraram-se nos anos posteriores, buscando entender em que medida as discussões dos anos 1960 sobre a valorização dos bens arqueológicos e os procedimentos para sua preservação; a relação entre natureza, cultura e patrimônio; os sentidos de monumento, da importância do entorno, da ambiência e das histórias de ocupação para tais sentidos; os impactos do desenvolvimento econômico e do crescimento urbano sobre os bens culturais e naturais; as possibilidades de compatibilização entre desenvolvimento e preservação; e ainda sobre o papel do turismo nesse processo influenciaram as ações da DPHAN e as políticas de preservação a partir dessa década. Além disso, vale buscar entender, nesta discussão, o papel transversal dos diversos sentidos atribuídos ao interesse público, e como essa noção foi, e vem sendo, utilizada de maneiras estratégicas para justificar as ações públicas de preservação. 


\section{REFERÊNCIAS}

\section{FONTES}

Arquivo Central do IPHAN/ Seção Rio de Janeiro

\section{ATAS}

IPHAN. Ata da reunião do Conselho do Patrimônio Histórico e Artístico Nacional, de 13 de junho de 1961, disponível em <http://portal.iphan.gov.br/uploads/atas/1961_03_35a_ reunio_ordinria_13_de_junho.pdf>, acesso em 16ago.2015.

Ata da reunião do Conselho do Patrimônio Histórico e Artístico Nacional, de 25 de junho de 1962, disponível em <http://portal.iphan.gov.br/uploads/atas/1962_02_39a_ reunio_ordinria_25_de_junho.pdf>, acesso em 16ago.2015

\section{COMUNICAÇÃO}

SAIA, Luís. O papel da Diretoria do Patrimônio Histórico e Artístico Nacional na proteção de sítios e paisagens. Comunicação apresentada na II Mesa Redonda de Informação sobre Conservação da Natureza, Rio de Janeiro, 30 de novembro a 7 de dezembro de 1967. ACI/RJ, AA01/ M066/ P05/ Cx. 0060/P 192.

\section{CORRESPONDÊNCIA}

ANDRADE, Rodrigo Melo Franco de. Ofício a Moniz Aragão, Ministro da Educação e Cultura, 20/10/1966a. ACI/RJ, AA01/ M066/ P05/ Cx. 0059/ P190.

Ofício a John M. Howe, chefe da Missão da UNESCO no Brasil, em 22/11/1966b. ACI/ RJ, AA 01/M066/P05/Cx. 0059/P. 0190

Ofício a Ali Vrioni, diretor do Departamento Cultural da UNESCO, 05/12/1966c. ACI/ RJ, AA 01/M066/P05/Cx. 0059/P. 0190.

CHAGAS FILHO, Carlos. Carta a Rodrigo Melo Franco de Andrade, em 21/06/1966 - Arquivo Central do IPHAN/ Seção Rio de Janeiro, AA 01/M066/P05/Cx. 0059/P. 0190.

MINISTÉRIO DAS RELAÇÕES EXTERIORES (MRE). Ofício enviado à DPHAN, em 26/06/1968. ACI/RJ, AA01/M066/CX. 59/P0189.

SOEIRO, Renato. Memorando a Rodrigo Melo Franco de Andrade, em 21/06/1966. ACI/RJ, AA 01/M066/P05/Cx. 0059/P. 0190.

Ofício a Nestor dos Santos Lima, Ministro da Relações Exteriores, em 14/11/1968, ACI/RJ, AA 01/M066/P05/Cx. 0059/P. 0190. 


\section{DOCUMENTOS INTERNACIONAIS}

UNESCO. Comité d'experts internationaux pour la mise em valeur du patrimoine culturel par le développement économique - Rapport final. Paris: UNESCO, 1968. ACI/RJ, AA01/M066/CX. 59/P0189.

UNESCO. Summary of the Responsibilities of the United Nations Organizations in the field of Tourism in: Review of the work of the United Nations System of Organization and of its planning and co-ordination (Report of the Secretary-General), 1972b parágrafo 89 (Originalmente publicado por UNESCO-SOC como Document E/ 5140/ 25 de maio de 1972). ACI/RJ. AA01/ M066/ P03/ CX 0046/ P 0153.

\section{DOCUMENTOS IMPRESSOS}

CURY, Isabelle (org.). Cartas Patrimoniais. $3^{\text {a }}$ edição rev. e ampl.. Rio de Janeiro: IPHAN, 2004.

UNESCO. Constituição da Organização das Nações Unidas para a Educação, a Ciência e a Cultura, 1945. Disponível em: <http://unesdoc.unesco.org/images/0014/001472/147273por. pdf>, acesso em 05 dez. 2015.

UNESCO. Declaração dos Princípios da Cooperação Cultural Internacional, 1966. Disponível em: <http://direitoshumanos.gddc.pt/3_20/IIIPAG3_20_1.htm>, acesso em 05 dez 2015.

UNESCO. Convenção sobre a Proteção do Patrimônio Mundial, Cultural e Natural, 1972a. Disponível em <http://whc.unesco.org/archive/convention-pt.pdf>, acesso em 05dez.2015.

\section{LEGISLAÇÃO}

BRASIL. Constituição dos Estados Unidos do Brasil, 10 de novembro de 1937. Diário Oficial da União - Seção 1 - 10/11/1937, Página 22359, 1937 a.

BRASIL. Decreto-lei $n^{\circ} 25$, de 30 de novembro de 1937. Organiza a proteção do patrimônio histórico e artístico nacional. Diário Oficial da União - Seção 1 - 6/12/1937, Página 24056, 1937 b.

BRASIL. Decreto-Lei ${ }^{\circ}$ 3866, de 29 de novembro de 1941. Dispõe sobre o tombamento de bens no Serviço do Patrimônio Histórico e Artístico Nacional. Diário Oficial da União - Seção 1 - 29/11/1941, Página 22368. 1941.

BRASIL. Lei $\mathrm{n}^{\circ}$ 3924, de 26 de julho de 1961. Dispõe sôbre os monumentos arqueológicos e pré-históricos. Diário Oficial da União - Seção 1 - 27/7/1961, Página 6793 ,1961.

BRASIL. Decreto-Lei $n^{\circ} 227$, de 28 de fevereiro de 1967. Dá nova redação ao Decreto-lei $\mathrm{n}^{\circ}$ 1.985, de 29 de janeiro de 1940. (Código de Minas). Diário Oficial da União - Seção 1 28/2/1967, Página 2417. 1967.

BRASIL. Decreto n ${ }^{\circ}$ 62.203, de 31 de janeiro de 1968. Extingue o Conselho de Fiscalização de Expedições Artísticas e Científicas no Brasil e dá outras providências. Diário Oficial da União - Seção 1 - 5/2/1968, Página 1137. 1968. 
BRASIL. Decreto $n^{\circ}$ 65.057, de 26 de agosto de 1969, Dispõe sobre a concessão de licença para a realização de Expedições Cientificas no Brasil e dá outras providências. Diário Oficial da União - Seção 1 - 27/8/1969, Página 7276. 1969.

BRASIL. Lei $\mathrm{n}^{\circ}$ 6938, de 31 de agosto de 1981. Dispõe sobre a Política Nacional do Meio Ambiente, seus fins e mecanismos de formulação e aplicação, e dá outras providências. Diário Oficial da União - Seção 1 - 2/9/1981, Página 16509. 1981.

\section{PERIÓDICOS}

A CHAVE do Império. Última Hora, Rio de Janeiro, 17/08/1972.

BELTRÃO, Maria da Conceição; LARAIA, Roque de Barros. O método arqueológico e a interpretação etnológica. Revista do Serviço do Patrimônio Histórico e Artístico Nacional, Rio de Janeiro, $\mathrm{n}^{\circ} 17, \mathrm{p} .203-218,1969$.

CARTA do Rio de Janeiro, ponto final. Correio da Manhã, Rio de Janeiro, 26/08/1972.

COSTA, Adroaldo Mesquita da. Patrimônio Histórico e Artístico Nacional - Tombamento Desapropriação. Revista de Direito Administrativo, Rio de Janeiro, n 82, p. 341-346, 1965. Disponível em: http://bibliotecadigital.fgv.br/ojs/index.php/rda/article/view/27827/26703, acesso em: 05 dez. 2015.

CRULS, Gastão. Arqueologia amazônica. Revista do Serviço do Patrimônio Histórico e Artístico Nacional, Rio de Janeiro, no 6, p.169-220, 1942.

LAMEgo, Alberto. Os Sete Povos das Missões. Revista do Serviço do Patrimônio Histórico e Artístico Nacional, Rio de Janeiro, n 4, p.55-82, 1940.

LOPES, Raimundo. A natureza e os monumentos culturais. Revista do Serviço do Patrimônio Histórico e Artístico Nacional, Rio de Janeiro, nº 1, p. 77-96, 1937.

TORRES, Heloisa Alberto. Contribuições para o estudo da proteção ao material arqueológico e etnográfico no Brasil. Revista do Serviço do Patrimônio Histórico e Artístico Nacional, Rio de Janeiro, ${ }^{\circ}$ 1, p. 9-30, 1937.

UNESCO pediu há dois anos defesa do nosso patrimônio histórico. O Globo, Rio de Janeiro, 21/12/1966.

\section{LISTAGENS}

IPHAN. "Lista de bens tombados e processos em andamento (1938-2015)" Disponível em <http://portal.iphan.gov.br/uploads/ckfinder/arquivos/Lista_Bens_Tombados_pelo_ Iphan_2015.pdf>, acesso em 05 dez. 2015. 


\section{LIVROS}

ANDRADE, Rodrigo Melo Franco de. Brasil: Monumentos Históricos e Arqueológicos. Rio de Janeiro: IPHAN, 2012.

ANDRADE, Rodrigo Melo Franco de. Conservação de conjuntos urbanos. In: RODRIGO e o SPHAN. Rio de Janeiro: Minc/SPHAN/Pró-Memória, 1987.

\section{RELATÓRIOS}

Arquivo Central do IPHAN/ Seção RJ e Biblioteca Noronha Santos

COREMANS, Paul. Brésil - La preservation du patrimoine culturel. Paris: UNESCO, 1964.

HABIB, Pierre. Rapport de Mission au Brésil du 28 mai au 4 juin 1979. Paris: UNESCO, 1979.

PARENT, Michel. Protection et mise en valeur du patrimoine culturel brésilien dans le cadre du dévéloppement touristique et économique. Paris: UNESCO, 1968.

SHANKLAND, Graeme (Relatório sobre Rio de Janeiro, Bahia, Cachoeira, Belo Horizonte, Ouro Preto, Congonhas, Sabará, Parati e Município de Parati entre 21 de fevereiro e 11 de março de 1969);

São Salvador de Todos os Santos. Town Planning, Conservation, and Tourism. A Report to UNESCO. Londres: s.1., s.d.;

STIRUM, Fréderic de Limburg. Plan National de mise en valeur de Parati dans le cadre d'um dévéloppement touristique. Paris: UNESCO, 1968.

VIANA DE LIMA, Alfredo Evangelista. Brésil - Renovation et mise en valeur d'Ouro Preto. Paris: UNESCO, 1970.

Brésil - Renovation et mise en valeur d'Ouro Preto. (Second Raport) Paris: UNESCO,

1972.

Relatório e propostas para a Conservação, Recuperação e Expansão - Estado do Maranhão/ Alcântara. Porto, 1973a.

Relatório e propostas para a Conservação, Recuperação e Expansão - Estado do Maranhão/São Luís. Porto, 1973 b.

. Relatório sobre missão a Laranjeiras e São Cristóvão, Sergipe. Porto, 1978a.

. Relatório sobre missão a Penedo e Marechal Deodoro, Alagoas. Porto, 1978b. 


\section{SÍTIOS ELETRÔNICOS}

<http://www.humanas.ufpr.br/portal/cepa/outras-pesquisas>

<http://www2.planalto.gov.br/@@busca?SearchableText=legisla\%C3\%A7\%C3\%A3o>

<http://www2.camara.leg.br/>

$<$ http://portal.iphan.gov.br/>

$<$ http://www.unesco.org/new/en/unesco/resources/online-materials/publications/unesdocdatabase/>

\section{LIVROS, ARTIGOS, TESES E OUTRAS PUBLICAÇÕES}

AGUIAR, Leila Bianchi. Turismo e preservação nos sítios urbanos brasileiros: o caso de Ouro Preto. 2006. Tese (Doutorado em História) - Instituto de Ciências Humanas e Filosofia, Universidade Federal Fluminense, Niterói, 2006.

BARRETO, Cristiana. A construção de um passado pré-colonial: uma breve história da arqueologia. Revista USP, São Paulo, n. 44, p. 32-51, dez.-fev. 1999-2000.

BRASIL. Ministério da Educação e Cultura. Secretaria do Patrimônio Histórico e Artístico Nacional, Fundação Nacional Pró-Memória. Proteção e revitalização do patrimônio cultural no Brasil: uma trajetória. Brasília: MEC-SPHAN/Pró-Memória, 1980a.

CALABRE, Lia. Políticas culturais no Brasil - dos anos 1930 ao século XXI. Rio de Janeiro: Editora FGC, 2009.

CHUVA, Marcia. Os arquitetos da memória. Sociogênese das práticas de preservação do patrimônio cultural no Brasil (1930-1940). Rio de Janeiro: UFRJ, 2009.

CORRÊA, Sandra Rafaela Magalhães. O Programa de Cidades Históricas (PCH): por uma política integrada de preservação do patrimônio cultural - 1973/1979. 2012. Dissertação (Mestrado em Arquitetura e Urbanismo) - Universidade de Brasília, Brasília, 2012.

DELPHIM, Carlos Fernando Moura. Patrimônio Cultural e Geoparque. Geologia USP, Publ. espec., São Paulo, v. 5, p. 75-83, outubro 2009. Disponível em <http://ppegeo.igc.usp.br/ scielo.php>, acesso em 12 jul. 2015.

FLORES, Alicia Pérez e MIGUEZ, Paulo César. A cooperação cultural na perspectiva da Unesco. Trajetória e expectativas. Políticas Culturais em Revista, Salvador, 1 (8), 2015, p. 106-120. Disponível em <http://www.portalseer.ufba.br/index.php/pculturais/article/ viewFile/13443/9752>, acesso em 20 mai. 2016.

FONSECA, Maria Cecília Londres. Da modernização à participação: a política federal de preservação nos anos 70 e 80. Revista do Patrimônio Histórico e Artístico Nacional, Brasília, $\mathrm{n}^{\mathrm{o}} 24$, p. $153-163,1996$.

Maria Cecília Londres. O Patrimônio em processo: trajetória da política federal de preservação no Brasil, $2^{\mathrm{a}}$ ed.. Rio de Janeiro: Editora UFRJ; MinC/IPHAN, 2005. 
FRANCO, José Luiz de Andrade. O cuidado da natureza: a Fundação Brasileira para a Conservação da Natureza e a experiência conservacionista no Brasil: 1958-1992. Textos de História, Brasília, vol. 17, no 1, p. 59-84, 2009. Disponível em <http://periodicos.unb.br/index. php/textos/article/view/1666>, acesso em 20 mai. 2016.

IPHAN. Caderno de Estudos do PEP Cronologia e Bibliografia das Práticas de Preservação do Patrimônio Cultural. Rio de Janeiro: IPHAN, 2009.

LEAL, Claudia Feierabend Baeta (org). As Missões da UNESCO no Brasil: Michel Parent. Rio de Janeiro: IPHAN, 2008.

As missões da UNESCO no Brasil: Paul Coremans. In: XXVI Simpósio Nacional de História ANPUH, 2011, São Paulo. Anais..., São Paulo, julho 2011. Disponível em: <http://www.snh2011.anpuh.org/resources/anais/14/1312827174_ARQUIVO_ AsmissoesdaUNESCOnoBrasil-PaulCoremans.pdf>, acesso em 05 dez. 2015.

LIMA, Tânia Andrade de. Patrimônio arqueológico, ideologia e poder. In: $2^{\circ}$ Encontro Nacional de Preservação de Bens Culturais, Belo Horizonte, 1987. Anais..., Belo Horizonte, IAB; SPHAN-FNpM, p. 24-25. Disponível em <http://revista.sabnet.com.br/index.php/revistade-arqueologia/article/view/249>, acesso em 27 nov. 2015.

MOTTA, Lia; SILVA, Maria Beatriz Resende. Inventários de identificação: um panorama da experiência brasileira. Rio de Janeiro: IPHAN, 1998.

MOTTA, Lia; THOMPSON, Analucia. Entorno de bens tombados. Rio de Janeiro: IPHAN, 2010.

OLIVEIRA, Mônica Castro de Oliveira. O patrimônio como ambiente: o papel do IPHAN no licenciamento ambiental. 2015. Dissertação (Mestrado em Preservação do Patrimônio Cultural) - IPHAN, Rio de Janeiro, 2015.

PEREIRA, Cecília Ribeiro. O turismo cultural e as Missões Unesco no Brasil. 2012. Tese (Doutorado em Desenvolvimento Urbano, MDU) - Universidade Federal de Pernambuco, Recife, 2012.

PEREIRA, Julia Wagner. O Tombamento: de instrumento a processo na construção de narrativas da nação. 2009. Dissertação (Mestrado em Museologia e Patrimônio) - Coordenação do Programa de Pós-Graduação em Museologia e Patrimônio, UNIRIO / MAST, Rio de Janeiro, 2009.

RABELLO, Sonia. O Estado na preservação de bens culturais: o tombamento. Rio de Janeiro: IPHAN, 2009.

RUBINO, Silvana. O mapa do Brasil passado. Revista do Patrimônio Histórico e Artístico Nacional, Brasília, no 24, 1996, pp. 97-105.

SANT'ANNA, Márcia. Da cidade-documento à cidade-monumento. A norma de preservação de áreas urbanas no Brasil (1937-1990). Salvador: Oiti Editora, 2015.

SCIFONI, Simone. A construção do patrimônio natural. 2006. Tese (Doutorado em Geografia) - Faculdade de Filosofia, Letras e Ciências Humanas da Universidade de São Paulo, São Paulo, 2006. 
SILVA, Regina Coeli Pinheiro da. Sobre a Preservação dos sítios arqueológicos brasileiros. Revista do Patrimônio Histórico e Artístico Nacional, Brasília, no 22, pp. 210-211. 1987.

Compatibilizando os instrumentos legais de preservação arqueológica no Brasil: o Decreto-lei no 25/1937 e a lei no 3924/1961. Revista de Arqueologia, São Paulo 9, p. 9-23, 1996, disponível em <http://revista.sabnet.com.br/index.php/revista-de-arqueologia/article/ view/295>, 20 mai. 2016.

SIMÃO, Lucieni de Menezes. Elos do patrimônio: Luiz de Castro Faria e a preservação dos monumentos arqueológicos no Brasil. Boletim do Museu Paraense Emilio Goeldi, Ciências Humanas, Belém, v. 4, n. 3, p 421-435, set-dez-2000.

SOUZA, João Vitor Campos de. Congressos Mundiais de Parques Nacionais da UICN (19622003): registros e reflexões sobre o surgimento de um novo paradigma para a conservação da natureza. 2013. Dissertação (Mestrado em Desenvolvimento Sustentável) - Centro de Desenvolvimento Sustentável, Universidade de Brasília, Brasília, 2013.

TELLES, Mario Ferreira de Pragmácio. Direitos culturais e a proteção jurídica do patrimônio arqueológico brasileiro: notas sobre a Lei 3.924/61. Disponível em <http://www. direitosculturais.com.br/artigos_interna.php?id=43>, acesso em 17 nov. 2015.

UNESCO. Marco estratégico para a Unesco no Brasil. Brasília: UNESCO, 2006. Disponível em: <http://unesdoc.unesco.org/images/0014/001475/147544por.pdf>, acesso em 05 dez. 2015.

UNESCO. World Heritage Information Kit. Paris: UNESCO World Heritage Centre, 2008. Disponível em <http://whc.unesco.org/documents/publi_infokit_en.pdf>, acesso em 10 abr. 2016. 